\title{
Climate change and strategic low-carbon planning in African cities after COVID-19: inclusiveness or chaos?
}

\author{
Xavier Lemaire
}

\begin{abstract}
Cities in sub-Saharan African countries are feeling the impact of climate change with an increase in climate refugees and they have to deal with more intense flooding, land degradation and erosion, droughts, and heatwaves affecting in particular the poor living in informal settlements. Strategies on how to adapt and move to more resilient cities are being designed. But the question is how this transition can be done while municipalities in subSaharan Africa are facing difficulties coping with demographic growth, budget scarcity, and poor governance. Most local authorities in sub-Saharan Africa have consistently failed to address the fundamental basic needs of communities, even before the current acute environmental crisis. This paper analyses the persistent urban planning bias preventing transition to sustainability, emerging alternative strategic options promoting resilience and inclusivity while moving toward low-carbon cities, and how the discourse on post-COVID cities is relevant to the context of urban Africa.
\end{abstract}

Keywords: Climate change impact, extreme heat, flood, informal settlements, strategic urban planning, sub-Saharan Africa, low-carbon transition, neoliberalism, social status, car-free city, climate adaptation, inclusiveness.

Note on the author: Xavier Lemaire is a Senior Research Associate at the Institute for Sustainable Resources-University College London. A sociologist and socio-economist specialising in the evaluation of public policies, he has led policy-oriented research projects linked to the energy transition in the Global South for the last twenty years.

(C) The author(s) 2021. This is an open access article licensed under a

Creative Commons Attribution-NonCommercial-NoDerivs 4.0 Unported License 


\section{Introduction}

This article reflects on the impact of climate breakdown on African cities. The relations between social status consumption and the transition to low-carbon cities and societies need to be explored. Inequalities in sub-Saharan African cities are not only shocking but could block any form of sustainability transition. The desire for over-consumption and the high-carbon way of life by the elite and the growing upper-middle class, combined with a top-down process of spatial segregation, could lead to the persistent marginalisation of the poor, and, in a context of weak governance and scarcity of resources, render any climate adaptation impossible. ${ }^{1}$ But the emerging practices of some African cities could challenge the social imaginary of stakeholders intervening in the field of urban planning by proposing concrete paths of mitigation and adaptation.

Otherwise, if urban planning continues to be left to practices disconnected from the daily lives of the poor and to support the marketisation of cities, climate change is likely to accelerate the dislocation of cities as urban space (that is, space of urbanity/civilisation). This process of fragmentation/privatisation-well engaged all around the world - tends to be exacerbated in sub-Saharan African countries; this is due to a general lack of capacity of intervention from local authorities and outdated and inadequate notions of what are contemporary forms of urbanism assimilated to modernisation. The absence of reflexivity amongst planning communities leads to the reproduction of the same errors; a paradigm shift based on the inclusion of all stakeholders in planning processes is needed for the complexity of cities to become manageable and avoid systemic failures (Coaffe \& Lee 2016: 73-247).

The literature on African urban planning has focused until now on the multiple barriers to sustainable transition, notably the weak governance capacity of African municipalities and the disconnection between urban development policies and local realities. There has been only limited literature on concrete paths for a sustainable transition in cities of the Global South, even at an international level; the call for citizen participation in urban planning and for an 'epistemic community' is not recent but until now has not so often been put into practice (Pieterse 2006, Lemaire \& Kerr 2014). But the acceleration of climate change effects and environmental degradation is putting cities even more at an existential crossroads which seems to require radical changes in mindset and urban planning practices (Cobbinah 2021).

African civil servants and elected members do face daily difficulties in administering cities that are quite different from their European counterparts. This paper aims to

${ }^{1}$ Equity, community participation, and integration of diversity appear to be prerequisites for resilience (Bahadur et al. 2013). 
understand what low-carbon strategies could be grounded in the reality of an African city. It is based on a literature review on urban planning in Africa, notably critical books, reports, and papers from African urban planners and researchers, focusing on what needs to be changed to make African cities resilient to climate change and how ongoing discussions of post-COVID cities could realistically apply to African cities. ${ }^{2}$ After characterising African cities and the impact of the climate crisis in urban sub-Saharan Africa, this paper reviews alternative models for low-carbon and resilient cities that are attracting renewed interest with the advent of COVID-19. Are these models adapted to the context of urban Africa? If not, how could they be adapted? By mobilising what resources? Knowing that African countries generate only a small amount of greenhouse gas emissions, are mitigation measures useful or should authorities focus on adaptation measures? In brief, what could low-carbon transition mean in the context of sub-Saharan African cities?

\section{African cities and climate breakdown}

\section{Sub-Saharan African cities as an archetype of the urban crisis?}

In the discourse produced by international organisations, non-governmental organisations (NGOs), media, consultants, and researchers, African cities may be presented as places of chaos, uncontrolled growth, and poor governance. A dystopian future would lead to the perpetuation of bleak living conditions for their poorest inhabitants (Davis 2006). Climate destabilisation would further condemn them to an endless spiral of depression and violence, as African cities would have no means to adapt (Planitz 2019).

Cities in sub-Saharan Africa are diverse and the use of a generic term like 'African cities' remains debatable (Myers 2011: 2-7). ${ }^{3}$ The former view of African cities as hopeless places of chaos can be tainted with racism and neocolonialism. The term

\footnotetext{
${ }^{2}$ This article is based on a literature review of emerging innovative urban planning practices; it also builds on discrete observations in several municipalities in sub-Saharan Africa during recent research-action projects co-led by the author on low-carbon society transitions; notably an EPSRC-DfID project on Supporting African Municipalities in Sustainable Energy Transition (2013-17) in South Africa, Ghana, and Uganda; this four-year policy-oriented project about integrating energy in municipal action involved informal interactions with African officials from six African municipalities during a number of workshops and capacity building events.

${ }^{3}$ This article aims to contrast the situation of African cities with their European counterparts. African urbanisation is different from that of other regions of the world due to the history and governance of the region (Dodman et al. 2017).
} 
'African cities' is often used de facto to describe urban places that do not comply with the ideal of a city as incarnated by Western cities; they are places of 'failed modernity' defined by a lack of, more than the result of, any autopoiesis/endogenous creation. On the contrary, grass-roots actors emphasise the capacity of resilience and creativity of the poor, which could lead to a new imaginary (Harrison 2006). For a 'neutral' observer which we aim to be, the accumulation of challenges faced by African cities does look daunting. Active adaptation strategies, aiming at promoting transformational city models and going beyond coping mechanisms, are needed (Bulkeley 2013: 142-89).

If the archetype of a doomed megapolis like Lagos conceals diverse urban forms, small and medium-sized African cities, where around half of urban Africans live, do not appear to be better off than the large conurbations (Gandy 2006, Dodman et al. 2017, Satterthwaite 2017). Most African cities tend to face similar issues when it comes to basic services/functionalities - issues unknown in OECD countries, or less acute: a shortage of electricity supply, lack of appropriate sanitation network, explosive accumulation of solid waste with a limited capacity for treatment, reduced mobility due to permanent and inextricable traffic congestion, a high level of air pollution, etc. Rapid human growth and poor state capacity of intervention are common in all African countries, and, if patterns of urbanisation can vary (AfDB et al. 2016: 155-8), slums are preponderant and are particularly vulnerable to climate change (Williams et al. 2019). In 2015, 59 per cent of the urban population in subSaharan Africa was living in informal settlements against 28 per cent in Asia and the Pacific (UN-Habitat 2016: 8). African cities also have the commonality of most of them being located in very-low-income countries ${ }^{4,5,6}$ and the African population is very young compared to other continents, which makes inhabitants even more vulnerable. ${ }^{7}$

Another common feature of African cities is the colonial heritage present in the physical urban space of African city centres and in the persistent way that urban planners function with variations according to the former colonisers' country (Watson \& Odendaal 2012, Silva 2015). Inherited urban planning practices in Africa are still based on a top-down approach where planners try to control and allocate space

\footnotetext{
${ }^{4}$ Human growth can reach up to 6 per cent per year. https://data.worldbank.org/indicator/SP.URB. GROW?locations $=$ ZG

${ }^{5}$ The majority of failed states, critically weak states, and weak states are located in sub-Saharan Africa (Rice \& Patrick, 2008).

${ }^{6}$ Some cities in Asian and Latin American countries face the same difficulties as African countries, linked to limited capacity of intervention due to limited financial resources and poor governance. But 36 out of the 47 least developed countries in the world can be found in sub-Saharan Africa. https://www. oecd.org/dac/financing-sustainable-development/development-finance-standards/DAC_List_ODA_ Recipients2018to2020_flows_En.pdf

${ }^{7}$ In 2015, children under 15 accounted for 41 per cent of the African population against 26 per cent in Latin America and 24 per cent in Asia (Dodman et al. 2017, quoting UN-DESA 2015).
} 
according to preconceived ideas transferred from the Global North of what is a good city for the dominant class, leaving aside the poor (Coquery-Vidrovitch 1991, Watson 2009). Segregation was and remains at the core of urban planning in African cities, even if urban dynamics always evade social control and fixed territorialities (Polomack 2010); the spatial separation between white colonisers and indigenous communities has mutated into:

1. social segregation according to income and location in the city along with ethnicity, a marker of social status in the post-colonial city where urban dwellers continue to be rural subjects ruled by traditional leaders instead of citizens (Beall 2006);

2. the separation between the formal city serving external interests-planned and benefiting from the minimal attention of decision-makers and the informal cityuncontrolled by urban planners and often seen as a chaotic space to be organised, a place filled with undesirable constructions producing (in the view of officials) a poor image of the city.

The idea of segregation as a fundamental driver of urban planning in Africa comes on top of:

3. the radical urban planning philosophy inspired by Le Corbusier $(1929,1964$, 1973), notably separating urban space into urban functions between work, leisure, and residential, and the idea of a modern city based on a strict grid pattern (as opposed to the informal unplanned city, which is to be eradicated);

4. the fragmentation of public action between different administrations with little horizontal communication-aka the silo effect-which translates into uncoordinated territorial actions.

Climate adaptation would imply critical reflexivity on maladaptive practices and integrative policies to reverse these four centrifugal tendencies, This paper will now address these points in more detail.

\section{Impact of climate destabilisation in urban Africa}

Climate destabilisation is, along with other types of environmental degradation, impacting cities in Africa in multiple ways. Africa is considered to be the most vulnerable continent to climate events due to the vulnerability of agricultural systems and its low-level capacity for adaptation linked to its poverty (Niang et al. 2014). The repetition of extreme weather events, their intensity and their severity create a new situation where urban planning practices need to build resilience around uncertainty; a permanent succession of disruptive impacts could otherwise have a systemic and cumulative debilitating effect on the functionality of a city. 
One noticeable impact of climate destabilisation is the sudden increase in internal and inter-regional migration linked to the loss or degradation of livelihoods in rural areas. The number of persons displaced by disasters in Africa was been estimated to have been around 21 million between 2008 and 2019 (IDMC 2019); however, migration always results from a complex of causation issues, making estimates of the number of climate or environmental refugees highly debatable (Parnell \& Walawege 2014). ${ }^{8}$ Refugees can resettle in camps, informal settlements, or squats near or within African cities. ${ }^{9} 10$

African cities seem to have a high capacity for the integration of newcomers. The impact of global migration flux in African countries might generate less tension than in Europe; ${ }^{11}$ contrary to common belief, refugees tend to integrate quickly and, far from being passive victims, can consolidate transnational trade networks (Campbell 2006: 125-47). Nevertheless, a sudden influx of migrants can put pressure on weak infrastructure and the job market, potentially generating xenophobic tension or leading to migrant communities being neglected (Asibey et al. 2021).

Major cities in Africa are located within coastal areas or near large rivers: ${ }^{12}$ they are already feeling the effects of land erosion, which reduces the space available for inhabitants and is highly disruptive of their social activities. ${ }^{13}$ The recurrence of flooding is a serious issue as it means a repeated loss of income and belongings, if not loss of lives (Douglas et al. 2008, Gough et al. 2019).

In hot and humid cities located in the subtropics, ${ }^{14}$ the increase in temperature exposes their inhabitants to heat stress aggravated by air pollution. Increased heat impacts the well-being of people who cannot afford air-conditioning (the vast majority); this is especially true for those living in informal settlements in rugged iron

\footnotetext{
${ }^{8}$ There is no established definition of climate refugees; they are persons being displaced either by the direct consequences of climate events, like droughts or floods, or indirectly when climate events have triggered armed conflicts (Apap 2019).

${ }^{9}$ Contrary to the imaginary belief socially constructed by an 'invasion' of Europe, the flux of migrants from Africa towards Europe is marginal compared to the inter-African flux (IDMC 2019).

${ }^{10}$ It is estimated that 60 per cent of refugees in the world live in urban areas (UNCHR 2016).

${ }^{11}$ Even with all the socio-economic problems African countries are facing, African politicians may tend to put less pressure on instrumentalising (related to the number of migrants in Africa compared to Europe) the question of migration than their Western counterparts.

${ }^{12}$ Access to the sea or a watercourse, which was an asset for cities allowing communication and access to resources like water or fisheries, could now be a handicap due to climate change.

${ }^{13}$ Saint-Louis of Senegal illustrates well the impact of erosion and modification of the regime of the Senegal River; fishermen have to move to Mauritania to pursue their activities (personal interview, January 2020).

${ }^{14}$ Since thermal comfort is dependent on temperature and humidity, cities under the tropic may be as vulnerable — even if the temperature remains around $30^{\circ} \mathrm{C}$ - as cities in arid regions.
} 
shacks where living conditions are truly unbearable (Gough et al. 2019, Pasquini et al. 2020). ${ }^{15}$

An increase in the spread of tropical infectious diseases is another possible consequence of climate change (Wu et al. 2016). The density of population and poor living conditions make tropical diseases more difficult to control in urban areas. The history of pandemics and tropical diseases shows that they have been instrumental in triggering changes in urban planning (Njoh 2012: 19-54). Environmental health could be a major field of intervention for African municipalities without requiring costly modern European solutions, by reconnecting urban planning with interdisciplinary health initiatives (Njoh 2012). Better sanitation, waste management, access to clean water, quality housing, and economic security for the breadwinner contribute as much as health infrastructure to preserving the health of a population.

Cities are dependent on their environment as they import natural resources. Repetitive droughts can reduce water supply and lead to restrictions in regions pumping too much water to satisfy the competitive needs of all stakeholders, notably farmers. Acute water scarcity is a reality in Southern Africa and can lead to severe water restrictions. ${ }^{16}$ Another consequence of climate change is the increase in food prices, which negatively impacts the poor, who devote the largest share of their budget to buying food.

\section{High-carbon versus low-carbon paths?}

The impact of climate change on African cities is and will be more severe than in European cities because of the already-existing conditions linked to subtropical and arid areas, the multiple difficulties African municipalities face in providing basic services, and their limited financial capacity, which prevents them from opting for easy technological fixes instead of costly ones. This latest limitation could paradoxically prove to be, in the long term, an incentive to implement more resilient sustainable

\footnotetext{
${ }^{15}$ Temperatures inside shacks can reach 3 to $8^{\circ} \mathrm{C}$ higher than outdoors; extreme heat has a significant impact on the life of slum inhabitants. These people prefer to sleep outside, which renders them vulnerable to mosquitoes and theft; their productivity at work is lower (Gough et al. 2019).

${ }^{16}$ After three dry years, Cape Town had to impose a quota of 50 1/inhabitant/day during the drought of 2018; the municipality contingency plans and aggressive communication campaigns, which mobilised everyone, eventually helped to push back Day Zero when the municipal supply of water would have been shut off (local media \& personal interview, January 2018). The water crisis could be blamed on climate change which increased uncertainties but also delayed infrastructure investment (Muller 2017). It may have led to a deepening of inequalities in water access with a reinforcement of the logics of commercialisation of water as the municipality withdrew the universal provision of free basic water and changed its tariff structure (Millington \& Scheba 2021); there has been also a multiplication of off-grid solutions by the wealthy (Simpson et al. 2020).
} 
solutions, as technological fixes can offer only temporary or partial solutions while sometimes being carbon-intensive and environmentally destructive.

Unlike their European or North American counterparts, African cities cannot opt for costly high-tech or capital-intensive solutions to protect their assets and inhabitants. They cannot build many extended seawalls and costly flood barriers to protect them from coastal erosion and rising sea-levels. Heat cannot be fought systematically with air-conditioning, which in Africa remains the privilege of upper-class houses, commercial buildings, and office complexes; costly water pipelines or desalinisation treatment plants are an option only for the wealthiest municipalities. ${ }^{17}$ Water scarcity could mean their demise.

In an African context, collective or individual high-carbon technologies with high capital or running costs tend to be out of reach of the poor and could reinforce their exclusion from the city, while low-carbon strategies could be more inclusive. If the capacity of African municipalities to intervene through the construction of major infrastructure seems limited, small collective actions may make a difference and reduce the impact of extreme events. Low-carbon solutions could go with lower capital costs and higher local job creation while being easier to maintain when built on local knowledge. $^{18}$

\section{What could the post-COVID city be in an African context?}

COVID-19 is widely considered to be an accelerator of change which has had a significant impact on cities; some cities have reacted better than others due to their governance capacity and more diverse and resilient economic systems (Sharifi \& Khavarian-Garmsir 2020, Simon et al. 2021). In the current debates about a postCOVID world, some well-known low-carbon and cost-effective urban design forms have been identified, which could not only contribute to adapting to climate change but also help mitigation while contributing to a reduction in social inequalities. The post-COVID city could be a sustainable city, a vernacular city, a healthy city, a bio-city, a post-carbon city, a good city, a liveable city, a resilient city, an inclusive city ... to take a few of the denominations from past research in urban studies (Ratho \& Lourdes John 2020).

\footnotetext{
${ }^{17}$ Cape Town, facing the severe water restrictions of 2018 , has opted for temporary desalinisation plants, which will be replaced by large-scale permanent ones. https://www.capetownetc.com/news/city-decommissions-standfontein-desalination-plant/ ${ }^{18}$ There are exceptions: the capital costs of individual renewable energy technologies like solar home systems are higher than conventional sources but cheaper to run on a life-cycle basis.
} 
Recurrent topics in the literature on what a city's future could be can be found around:

- low-carbon buildings or the vernacular city,

- soft mobility and the car-free city,

- the importance of green spaces or the bio-city,

- the recognition of urbanity as the creation of commons.

Unlocking sustainable cities implies action on those four points (Chatterton 2019). In the specific context of the Global South, the last point is particularly important as African cities are, for the most part, informally co-built by their inhabitants, and moving towards a more resilient city either against COVID-19 or climate change cannot be achieved without the recognition of this informality. ${ }^{19}$

\section{Elements of low-carbon socio-technical strategies}

\section{Low-carbon—-the vernacular city}

The rise of office blocks made of concrete, steel, and glass-symbols of modernity prevalent in the business areas of African capitals - goes along with the construction of commercial centres, luxury residential complexes, and miles and miles of suburban upper/middle-class houses (often in gated communities), representing a characteristic form of architecture imported from Western cities, which tends to valorise individual consumers/nuclear families. Sometimes architectural gestures relying on the recycling of local signs/shapes are mobilised for major buildings, which will act as a symbol of Africanity (Bekker \& Therborn 2012).

These modern (small or large) buildings can be costly to maintain; they tend to be energy-intensive and closed to their immediate environment, relying on air-conditioning, the use of artificial lights, lifts for high-rise buildings, and telecommunications of all sorts. Rising temperatures and an appeal to air-conditioning can put a strain on an already-overloaded electricity network that has, in most African countries, difficulties coping with increasing demand. ${ }^{20}$

\footnotetext{
${ }^{19}$ The fragility of African cities underlined at the beginning of the COVID-19 pandemic has been used as a call for change in Africa as in the rest of the world (UN-Habitat 2020).

${ }^{20}$ Air-conditioning and electric fans represent 10 per cent of all global electricity consumption today (IEA 2018). Incidentally, the multiplication of substandard air-con not only increases energy bills but also generates supplementary noise while extracting heat to eject it outside.
} 
However, low-carbon solutions exist for modern buildings both in the choice of materials and in the choice of design: concrete or steel which are carbon-intensive could be replaced by equivalent materials generating less carbon emissions (but currently costly to produce) (Bataille 2019) or more likely by cheaper vernacular materials like timber, bamboo, laterite, or clay ${ }^{21}$ (Agyekum et al. 2020). Passive housing ${ }^{22}$ in tropical areas may be still in its infancy, but the design of well-ventilated and shaded open space has existed for centuries without requiring any substantial energy input.

Residential housing could potentially evolve towards more vernacular forms with an architecture adapted to local climate conditions rejecting air-conditioning as a norm by relying on natural climate, ${ }^{23}$ using local materials could reduce the carbon intensity of buildings, create jobs, and help to mitigate climate change, ${ }^{24}$ but also contribute to adaptation to climate change as local materials can generate better insulation. However, this would imply an adaptation of building regulations (Heisel \& Kifle 2016: 166-76). Decentralised renewable energies like thermal solar ${ }^{25}$ may help to heat/cool buildings and provide hot water without imposing on the electricity network. Solar photovoltaic electricity is now cheap enough to power houses and contribute to a significant part of the electricity needs of commercial buildings. The recycling of water and collection of rainwater in closed tanks could help to reduce flooding and the consumption of clean water.

The poor who rely on self-construction of their homes on small parcels need access to materials providing better insulation - for a marginal cost, programmes providing roof insulation and wall insulation have been proven to make a significant difference in terms of thermal comfort. ${ }^{26}$ Providing adequate materials or basic structures can help them to consolidate/build their homes and give them better resistance to extreme events (Blair 2012). The adoption of minimal building regulations targeting informal settlements may lead to their observance, more than a set of complex regulations,

\footnotetext{
${ }^{21} \mathrm{https} / /$ inhabitat.com/11-green-building-materials-that-are-way-better-than-concrete/

${ }^{22}$ Passive houses are houses with a low carbon footprint; they combine high energy efficiency standards and a high level of insulation, and harness natural energy sources, which lead to very low need for conventional active source of energy for heating and cooling: passive sources are the Sun, or the heat coming from human bodies or produced by household appliances.

${ }^{23}$ Unfortunately, even if vernacular architecture is generating a growing interest worldwide, studies on the African continent remain rare (Nguyen et al. 2019).

${ }^{24}$ The carbon impact of African cities may still be low, but, due to their demography, the need to build new houses to accommodate urban dwellers cannot be fulfilled with conventional materials and norms without having a significant carbon impact.

${ }^{25}$ Solar water heaters are a simple technology which has been mature for decades, but is still largely ignored by policymakers. Some countries like Tunisia or South Africa managed to disseminate them at very large scale. See Lemaire \& Kerr (2018).

${ }^{26} \mathrm{https} / / /$ architizer.com/blog/practice/tools/architecture-for-a-change/
} 
which even most buildings in formal settlements ignore. Modernist building standards generate poverty and poor health (Njoh 2012: 86-91). Various delivery mechanisms of affordable housing can help the mass production of houses become more secure than self-constructed shacks (UN-Habitat 2011).

Buildings are part of an ecosystem, and acting on buildings alone is not enough. Speculation - rejecting inhabitants in suburbs where land is less expensive and fulfils the desires of families to obtain more space and security - tends to impose long commutes for work and shopping. More resilient cities implies not just new buildings but other types of ecosystems of buildings. As the ongoing COVID-19 crisis seems to be demonstrating, remote working and online shopping may become the new normal in African cities as in most European countries. Office blocks and commercial spaces are likely to be less needed and may give way to an allocation of space in the city centre to other users. Urban planning may have to completely revisit the design of the modern city due to a dramatic shift in habits. ${ }^{27}$

A wealth of literature has already been written on what post-COVID cities could be, and it seems urban policymakers, at least in OECD countries, have been proactive in implementing transformative actions from the very start of the crisis (OECD 2020). This new imaginary and habits of online social activities could become entrenched in African cities that are connected to high-speed Internet; but, while the use of mobile phones is widespread, only a minority have access to a computer. Deeply rooted social and cultural management norms can also intervene and derail the process of transitioning to teleworking and online shopping in countries where face-to-face relations are so important. ${ }^{28}$

But this debate around remote working involves employees from the formal sector. People in the informal sector have no such alternative and their livelihood, when it does not rely on providing services from their shack, implies gaining access to lively city centres and busy streets, which could come closer to where they live.

The recognition of the vernacular city is based on a recognition of the existence of low-cost/low-carbon ways of building a city where the inclusion of everyone leads to a global increase in standards of living while drastically reducing the carbon footprint of urban growth.

\footnotetext{
${ }^{27}$ It remains to be seen what kind of balance between remote working and office working will endure. But ecosystems built around commuting and working in city centres may never come back to their previous level of activity.

${ }^{28}$ In Nigeria and South Africa, the shift to remote working has been significant. To determine the future balance between remote and on-site working, the technical issue of access to reliable networks (Internet, electricity) at home versus at the office may be less important than embedded sociocultural habitus. But it seems that in the Global South as in the North, employees and employers have a mutual interest in carrying on with a hybrid mode. https://qz.com/africa/2053741/remote-work-risks-exploiting-workersin-low-income-countries/; https://www.infoq.com/articles/working-remotely-Africa/
} 


\section{Low-carbon mobility—-the car-free city?}

As transport infrastructure cannot keep up with the territorial expansion of African cities, urban mobility is becoming a critical challenge in most cities; the transport system in Africa is quite different from that in the Global North with a prevalence of informal/paratransit modes of transport (for example, collective taxis or minibuses). But these paratransit systems are seldom taken into consideration by policymakers who focus on large infrastructure projects more than on mobility itself (Klopp \& Cavoli 2019, Boutueil et al. 2020, Falchetta et al. 2021).

If mobility in a city is considered to be a major component of its efficiency, one of the constant characteristics of urban Africa is the prevalence of cars, which are, most of the time, moving very slowly. Some African cities now appear jammed with cars. The apparent paradox is that only a small minority of urban dwellers in African cities own or ever will own a car, which remains a luxury even for most segments of the emerging middle class. ${ }^{29}$ But the choice of allowing free rein for a mode of transport that can only benefit the elite and upper-middle class is rarely questioned in African countries, unlike in Europe (Pirie 2014: 133-47).

There would be so many reasons to question this choice, which is reflected in African countries, even more than in OECD countries, as the predominance of a habitus and a status symbol more than a rational choice (or a rational choice but just from the point of view of the African bourgeoisie). Cars destroy mobility and urbanity (Pitcher \& Graham 2006). First, a transportation system geared around cars implies a city built around cars with great distances between the different functionalities and services of a city - this imposes a financial burden on middle-class households who have to sacrifice a large share of their income to reimburse/buy a car, which means exclusion from mobility of the majority who cannot afford a car and have to rely on an inappropriate public transport system based on informal services from collective taxis and overcrowded public buses. ${ }^{30}$

Second, cars in a city create congestion, which leads to considerable wasted time, ${ }^{31}$ environmental costs in terms of air pollution, and consumption of urban space that could be devolved to uses besides roads, car parks, and other infrastructure. The paucity of infrastructure and the lack of planning create permanent traffic bottlenecks.

\footnotetext{
${ }^{29}$ The number of vehicles per inhabitant in sub-Saharan African countries is far below 100 per 1,000 inhabitants except in Southern Africa.

https://ourworldindata.org/grapher/road-vehicles-per-1000-inhabitants-vs-gdp-per-capita.

${ }^{30}$ Even if some African cities have implemented mass public transport, the informal sector represents an important share of public transport supply: between 35 per cent and 90 per cent (Falchetta et al. 2021).

${ }^{31}$ It is not uncommon in cities like Accra or Dakar to have to spend several hours per day commuting.
} 
Due to rapid demographic growth, a predict and provide ${ }^{32}$ approach to accommodate cars is impossible, and cities cannot cope with the expansion of car ownership and taxis. Third, the infrastructure around cars needs a considerable investment and maintenance budget, which may be subject to corruption and market distortion, which in cash-strapped African countries could be devoted to better uses (Gwilliam et al. 2008, Collier et al. 2015); it would be cheaper to build cities around alternative means of transport that could guarantee a more fluid mass transit.

Fourth, as anyone who has lived in Africa has realised, pedestrians are often completely forgotten by planners, not only because distances intended for car use are too great to be travelled on foot in a hot climate but because there are no proper sidewalks. This is sadly one of the main reasons for the extremely high number of fatalities in the Global South (World Bank 2014). Fifth, cars kill and mutilate not only vulnerable pedestrians, notably children, but also a high proportion of drivers; this proportion is a lot higher than in Western countries due to the poor state of local roads and often second-hand cars ${ }^{33}$ and the local norms of driving.

Last, the level of air pollution in some sub-Saharan African countries can be high, notably in the Sahel region where it is one of the highest in the world. ${ }^{34}$ This is linked to environmental factors, increased frequency of dust storms, ${ }^{35}$ and wood burning and in urban areas is seriously aggravated by an ageing fleet of cars that causes extreme pollution (UNEP 2020). Outdoor air pollution kills more than four million people worldwide every year; ${ }^{36}$ small PM10 and PM2.5 particles damage the health of not only the frail and vulnerable but of everyone. This impact can only be aggravated by the extension of urban areas.

In conclusion, the lack of priority given to public transport and the de facto priority given to cars is a typical example of the promotion of an inefficient and costly means of transport in urban areas. In the case of African cities, this choice appears even more absurd than in Europe, as it is more apparent that they guarantee the comfort and the benefit of the very few and clearly go against the benefit of the majority (that is, everyone - as permanent traffic congestion means inefficiencies, even for the privileged). Furthermore, most road infrastructure is in poor condition-only main roads are tarmacked and, even in formalised areas, public transport is deficient and

\footnotetext{
${ }^{32}$ This approach which consists of providing more roads to meet an ever-increasing demand is considered a dead end, even in OECD countries.

${ }^{33}$ In Africa, the market for new cars is small and the vast majority of cars are imported second-hand via semi-official networks from Europe or Asia (notably Japan); the absence of regulation makes Africa a 'dumping ground' for cars that do not meet pollution norms in their country of origin (UNEP 2020).

${ }^{34} \mathrm{https} / / /$ www.nasa.gov/topics/earth/features/health-sapping.html

${ }^{35} \mathrm{https}$ ://www.thinkglobalhealth.org/article/weathering-sahel

${ }^{36} \mathrm{https}: / /$ www.who.int/health-topics/air-pollution\#tab=tab_1
} 
dirt roads can be impassable in the rainy season. Mobility is seriously constrained for most inhabitants in African cities and the Automotive City in urban Africa represents an ideal of modernisation that is obsolete even before its full realisation.

Cities built around cars are particularly non-adapted to a changing climate: the level of air pollution can be deadly when temperatures rise; the tarmac of roads and the multiplication of thermal engines combined with the concrete of buildings create heat islands; the impermeability of roads increases flash flooding; dust from nontarmacked roads and the level of noise in the streets combined with the multiplication of high-rise structures blocking air flows prevent natural air-conditioning of buildings, since windows cannot be left open. ${ }^{37}$

With COVID-19, there has been a multiplication, particularly in OECD countries, of 'urban guerrilla' operations/tactical urbanism to reduce public space for cars and air pollution (Carmichael 2020): a reduction in the size of roads and streets allocated to cars is giving space to cyclists, electric mopeds, and scooters to make city centres pedestrian-friendly while planting trees and increasing green spaces. In short, building cities around the needs of humans can help them to be more resilient to climate change, as represented in the future of post-COVID cities. Until now, few African cities have embraced the concept of a car-free city, even if some African countries are now adopting monthly car-free days. ${ }^{38}$ Mass transit relying on high-capacity buses with dedicated lanes - Bus Rapid Transit - has just started to be successfully developed in South Africa; Africa is lagging far behind Latin America. The development of urban rail systems is, nevertheless, gaining traction in major African cities, with many projects under construction..$^{39}$ Addressing social inequalities in transport would imply making a clear choice in favour of collective public transport and soft low-cost modes of mobility and getting away from the supremacy of the car. Low-cost/lowcarbon (public transport/electric scooters) ${ }^{40}$ approaches goes with equal access and the democratisation of public space for everyone and against high-cost/high-carbon (the conventional car) or high-cost/low-carbon technologies (the electric car) which will remain in African cities the perk of the few and may lead to competition for scarce resources.

\footnotetext{
${ }^{37}$ Their isolation from the environment could be presented as a necessity due to the presence of IT devices - computers do not like humidity and dust.

${ }^{38} \mathrm{https}: / / \mathrm{www}$.unep.org/news-and-stories/story/car-free-days-are-taking-hold-african-cities

${ }^{39} \mathrm{https} / / / \mathrm{www}$. railwaygazette.com/news/regions/africa

${ }^{40}$ Public transport may imply substantial investment, but its cost per passenger $/ \mathrm{km}$ is low due to the high volume of passengers carried.
} 


\section{Occupation of space- - the recognition of informality?}

The occupation of urban space in African cities is a mix of standard urban planning that segregates people according to their social class/wealth and large areas of spontaneous informal settlements relegated to the margins of the official organised space but where the majority of inhabitants live. The post-colonial history of the urbanisation of African cities reveals that the authority's approaches constantly oscillate between 1) ignorance of informality, 2) eradication of informality by bulldozing informal settlements and policing informal activities, and 3) recognition of informality by upgrading informal settlements and enforcing light regulation of informal activities. However, ignorance and eradication seem to prevail and can be particularly ruthless. ${ }^{41}$

Definitions of what is informal are far from established (Coquery-Vidrovitch \& Nedelec, 1991, Simone \& Abouhani 2005: 237-8). Informal could essentially mean not informed by official directives from urban planners who consider with suspicion any spontaneous organisation from inhabitants who have to invent viable lives for themselves; informal settlements are actually socially organised even if they appear chaotic in the eyes of outsider/official planners, the latter sometimes being complicit in the not-so-spontaneous organisation of the informal urban space (Coquery, 1991: 197-203, Myers 2011: 71-8).

Furthermore, boundaries between officially organised space and informal chaotic space are blurred; even within officially organised urban spaces, informality can be found - that is, non-compliance with official rules: street vendors along main roads, backyard dwellers, and the subletting of rooms. Informality is everywhere in urban Africa, but this informality is rarely recognised by authorities who still tend to perceive it as a necessary evil part of African life or a failure of their official policies. The latter, by imposing rules that cannot be observed, create informality, which is being used as a power resource by the well-connected.

New forms of occupation of space in African cities mean better transparency and the democratic inclusion of informal urban forms, and a break with the persistent old reflex of attempting to erase or ignore informality. This applies particularly to informal constructions but also to street vendors and any other not officially agreed occupation of urban space. ${ }^{42} \mathrm{New}$ forms of occupation of space in Africa can only emerge if the

\footnotetext{
${ }^{41}$ For instance in Nigeria (Nuvanna 2015) and Zimbabwe (Potts 2006); in Francophone Africa, operations of eviction called 'déguerpissements' are also quite common.

${ }^{42}$ Streets in Africa are an extension of houses: places where people live and work and not just public space where people circulate. This is particularly true in informal settlements, as shacks are very small and inhabitants are used to managing their immediate surroundings without relying on municipalities; their involvement in the self-organisation of their living areas does not stop at the door of their house (Khalil et al. 2018: 71).
} 
capacity for creation and survival skills of inhabitants are recognised by authorities. It also implies recognising the influence of the past and a break with the heritage of colonialism still pregnant in Africa in the structuration of ideas (which translates into concrete constructions). What is a modern rational city in Africa based on a representation of an orderly city (that is, a city reinforcing colonial dominance) mobilising prejudices and racist bias?

The heritage of French, British, Portuguese, Belgian, German, Spanish, or Italian colonisation remains apparent in African cities with the structuration of streets in rectangular patterns and colonial buildings (now often in a poor state, left to squatters, and earmarked for future speculative redevelopment). Areas formerly demarcated during colonial times for the indigenous population and segregated from colonial quarters can also still be seen in the urban fabric: they were places where manpower would be available but under the social control of the Europeans. They include new areas with the construction of basic houses (townships) and the conservation/ demarcation of native quarters with their traditional construction; native quarters were perceived as unhealthy for Europeans, and inhabitants were deliberately left to their own fate and had to self-construct their houses (Coquery-Vidrovitch, 1991: 174-7).

Post-war master plans inspired by Le Corbusier's ideas of zoning aimed to create new intermediate neighbourhoods where an African urban educated elite and European middle class could live (Dalberto et al. 2013: 43-64). Immediate postcolonial urbanism has added a structuration/hierarchisation of space according to the income of inhabitants with the highest luxury standards of construction, with the best location for the elite and then a progressive diminution of standards as social status lowers (Massiah \& Tribillon, 1987: 52-5). Post-independence master plans designed by international consultants have only reinforced and entrenched such colonial practices (Cobbinah \& Darkwah 2017). This segregation has been amplified with a reduction in public intervention in the 1980s. Private developers are now in charge of the construction and expansion of the official city with limited oversight from municipalities. New social housing programmes tend to be scarce; private developers trying to maximise their profit are logically targeting, as a priority, inhabitants with some or high purchasing power.

Migrants and the poor are more than ever being left to their fate with no official property titles and, therefore, under the constant threat of eviction in places that are more often prone to flooding, landslides, and fire hazards ${ }^{43}$ The density of population in informal settlements can be high, causing limited access to basic services like water, sanitation, transport, and electricity, which means rubbish is dumped or burnt

\footnotetext{
${ }^{43}$ In the most rudimentary shacks, fire is a major hazard which can wipe out whole quarters; this is either due to accidental causes linked to the use of cookstoves and petrol lamps ... or it can be intentional as a way of pushing people to move out (Jones 2020: 148). Flooding is often considered as the major threat from climate change by the inhabitants of informal settlements (Busayo et al. 2019).
} 
everywhere, so conditions of hygiene can be deplorable, and the sense of insecurity is high. The multiplication of extreme natural events aggravates the precarious conditions of inhabitants living in informal settlements and, by extension, to those living in nearby neighbourhoods.

Climate adaptation would mean prioritising the reallocation of urban space according to differentiated risk zones. Allocating space for the poor in safe areas seems like a prerequisite instead of leaving vulnerable areas to vulnerable people who, in the current economic system, unavoidably occupy the interstices left where no developers can go because of the risk of flooding or landslides. This would mean pricing the land according to social and environmental criteria instead of leaving the allocation of space according to conventional market mechanisms. It would mean tackling the complex question of tenure insecurity as inhabitants living in a transient space are unlikely otherwise to invest time and money in building resilience and a political project in a specific place if they could be under the threat of eviction at any time (Simone \& Abouhani 2005: 10-24). In terms of land tenure, public authorities need to deal with non-statutory authorities, and transactions remain largely opaque (Simone 2004: 192-201, Magigi \& Drescher 2010, Kleeman et al. 2017). The privatisation of rights has led to a new customary land tenure with new relations of power, which have led to further marginalisation of the poor, who relied on informal networks and now find themselves more and more in competition with outsiders (Myers 2011: 83-6, Chimhowu 2019). In those conditions, control of urban allocation for climate adaptation means establishing a dialogue with communities. Climate adaptation of informal settlements also implies acting not only on buildings but also on the informal economy in general (Table 1).

The recognition of informality by giving support to the majority of inhabitants who live in an informal way instead of a minority could enhance and make more sustainable and rewarding already-existing low-cost/low-carbon ways of inhabiting the city and help to build a low-carbon expansion path for the city.

\section{The mobilisation of the human resource}

\section{Communities and environmental management}

The impact of climate change felt differently by social status implies different strategies of adaptation for different areas of a city (Table 1). Informality is a synonym for over-occupation, high density, and narrow streets, which renders external emergency intervention perilous due to difficult access. The absence of a proper sewage system, the lack of drains, and drains blocked by non-collected waste contribute to an increased likelihood of flooding and diseases in areas located in vulnerable zones. 
Table 1. Likely impacts of climate change on informal settlements and possible measures to adapt. Source: UN-Habitat (2018).

\begin{tabular}{|c|c|c|c|}
\hline $\begin{array}{l}\text { Projected } \\
\text { changes }\end{array}$ & $\begin{array}{l}\text { Examples of likely } \\
\text { impacts }\end{array}$ & $\begin{array}{l}\text { Implications for residents of informal } \\
\text { settlements \& people working in the } \\
\text { informal economy }\end{array}$ & $\begin{array}{l}\text { Possible measures to } \\
\text { adapt }\end{array}$ \\
\hline $\begin{array}{l}\text { Higher (and } \\
\text { increasing) } \\
\text { average } \\
\text { temperatures, } \\
\text { more hot days } \\
\text { and heat waves, } \\
\text { fewer cold days } \\
\text { — over nearly all } \\
\text { land areas }\end{array}$ & $\begin{array}{l}\text { Rise in mortality and illness } \\
\text { from heat stress in many } \\
\text { urban locations. } \\
\text { Extended range and activity } \\
\text { of some disease vectors - } \\
\text { including mosquito and } \\
\text { tickborne diseases. Increased } \\
\text { water and energy } \\
\text { demand }\end{array}$ & $\begin{array}{l}\text { Many informal settlements are very dense } \\
\text { with very little open/public space and } \\
\text { often with uninsulated corrugated iron } \\
\text { roofs and poor ventilation that contribute } \\
\text { to higher indoor temperatures. Lack of } \\
\text { public health measures to control disease } \\
\text { vectors. Largest impacts among groups } \\
\text { particularly vulnerable - infants and } \\
\text { young children, the elderly, expectant } \\
\text { mothers, those with certain chronic } \\
\text { diseases. Health risks for outdoor workers } \\
\text { and informal workers may not benefit }\end{array}$ & $\begin{array}{l}\text { Improved building design } \\
\text { to maximise natural } \\
\text { ventilation; set up locally } \\
\text { accessible health services; } \\
\text { provide education about } \\
\text { measures to reduce } \\
\text { transmission of disease } \\
\text { and reduce risk of } \\
\text { heatstroke/cold exposure. } \\
\text { Investing in green space, } \\
\text { renaturation and tree } \\
\text { planting }\end{array}$ \\
\hline
\end{tabular}

\begin{abstract}
More intense precipitation events and
\end{abstract} riverine floods

Wind storms with higher wind speeds

\author{
Increased \\ summer drying \\ over mid-latitude \\ continental \\ interiors and \\ associated risk of \\ drought \\ Intensified \\ droughts and \\ floods associated \\ with El Niño \\ events in many \\ different regions
}

Sea-level rise
Increased flood, landslide, avalanche and mud-slide damage resulting in injury and loss of life, loss of property and damage to infrastructure. Increased flood run-off often brings contamination to water supplies and outbreaks of water-borne diseases

Structural damage to buildings, power and telephone lines, communication masts and other urban infrastructure

Decreased water resource quantity and quality; decreased soil quality and risk of soil erosion; increased risk of forest/bush fire; decreased crop yields and higher food prices

Decreased agriculture and range-land productivity in drought-prone and floodprone regions from health and safety regulations

Many informal settlements concentrated on sites most at risk of flooding with poor quality housing less able to withstand flooding and a lack of risk-reducing infrastructure. Homes, possessions and income-generating assets are not covered by any public or private insurance. Transport infrastructure damaged affected workers

Relatively small increases in wind speeds can damage buildings, particularly as many informal settlements are composed of temporary or semi temporary housing. Also, informal utility services are likely to be damaged or cut due to extreme wind

Informal settlement residents usually facing more water constraints and are more vulnerable to food and water price rises

Impact on food availability and prices in urban areas

Many informal settlements close to the sea with poor quality housing and lacking drainage infrastructure
Building and infrastructure designs that incorporate flood and landslide resilience; improve drainage infrastructure locally and city flood management practices and systems; innovate to identify suitable disaster insurance products

Improve housing design and construction to withstand winds; improve construction and design of infrastructure

\author{
Addressing underlying \\ socio-economic factors \\ which affect poverty; \\ improve water \\ infrastructure and \\ affordability
}

Promote rooftop or urban gardening to supplement food sources. Strengthen livelihoods to increase incomes

Raise awareness of storm surges; construct protective infrastructure or explore relocation in a participatory manner

However, informality also means human resources and indigenous knowledge that, when mobilised, could help to increase resilience to climate change. Coastal erosion, landslides, and floods can be partly prevented by direct action from inhabitants as long as they receive some kind of support from authorities. Effective alert 
systems and disaster risk management need the full participation of local communities who possess the knowledge of the area in which they live (Kasei et al. 2019).

African cities need protected green spaces and green corridors to act as buffer zones and mitigate the impact of natural events and also to contribute to the wellbeing of their inhabitants. Green spaces and trees along streets have multiple benefits in terms of climate adaptation: the prevention of landslides and flooding, reduction of heat islands,$^{44}$ generation of income, and multiple services (Lwasa et al. 2013; du Toit et al. 2018). It is widely recognised that a healthy city implies a closer contact with nature and moves away from a predatory model to biophilic design and biomimicry (Chatterton 2019: 74-81); but, in most African cities, access to urban green infrastructure, notably for the poor, tends to diminish rapidly (Mensah 2014, Roy et al. 2018, Venter et al. 2020). Designated non-constructible zones do not remain without construction for long if buffer spaces created on paper are not benefiting local communities who then have no interest in protecting those areas.

Conservation areas are one possibility for providing green space, but only if combined with sustainable exploitation of forests, for the extraction of wood, urban agriculture, or recreational use. Environmental management would need to be more integrated (Cilliers et al. 2014, Padgham et al. 2015, Douglas 2018), as in rural areas, where instead of strict conservation areas opposed to development areas, mixed use is now being promoted (Andrade \& Rhodes 2012). Boundaries in urban areas should not be used to enforce strictly protected zones, but should favour mixed use with a progressive change of use.

This implies new forms of environmental management where concerns of local communities are part of the solution and not sidelined (Lindley et al. 2018), less shortterm thinking where market forces are prevalent, and more long-term planning, as land speculation does not recognise the value of non-built spaces. By giving their inhabitants control over their immediate environment which is then managed for and by local communities, and by letting local solutions emerge and complement large infrastructure discussed with local authorities, the risk of systemic failure of complex cities can be reduced (Satterthwaite 2011a).

\section{From elusive to effective participation}

Community participation is recognised as a way to favour inclusiveness by allowing the poor to explain what their priorities are; to mobilise people who will recognise solutions as theirs because they are co-designed by them and grounded in their

\footnotetext{
${ }^{44}$ In a survey conducted in informal settlements in Cairo, planting trees was the preferred low-tech, low-cost strategy to reduce heat islands followed by the use of facades, light-coloured painting, roof planting, fabric sheds, and wooden pergolas (Khalil et al. 2018: 71).
} 
reality; ${ }^{45}$ to make public services and administrations work together; and prioritise and promote integrated solutions because the community's needs are a common focus (Cobbinah et al. 2019, Leal Fihlo et al. 2019).

The idea of participation has evolved considerably from providing manpower to pre-established projects to empowerment, and the degree of openness of municipalities to civic participation can fluctuate (Burgess et al. 1997, Sarzynski 2015). But, if participatory planning has been a leitmotiv in the field of urban planning since the 1970s, it has led to few long-lasting achievements in urban Africa, as emerging effective demand-led partnerships driven by local communities with municipalities, the private sector, and donors still remain constrained, even if more and more recognised by all as a necessity in the face of an accumulation of risks (Leck et al. 2018). Community-based adaptation to climate change, which emerged at the beginning of the century, still needs to be upscaled (Okpala 2009: 20-2, McNamara \& Buggy 2017). There are multiple reasons for this: community participation takes time to put in place; donor aid projects have a limited life-cycle; turnover within municipalities and donor organisations can be high; delimitation of responsibilities remains unclear-all these factors leaving communities without clearly identified interlocutors.

Opacity of power is also a condition of power for some stakeholders. Participation implies power and knowledge sharing, which is difficult to conceive for politicians and technocrats who consider themselves as unique possessors of decision and planning capacity; participation also needs to answer the question of who to engage with, as community leaders often fail to represent the most marginalised and women (Lemaire \& Kerr 2017a) and participation itself can lead to an exclusionary/marginalisation process or participation following an already-established agenda (Aylett 2010, Rigon 2014, Fredericks 2018: 101-21).

This could be avoided by greater institutional stability and brokers between the official world and communities spending time to understand local dynamics of power and reach out the voiceless; it implies combining knowledge that has been produced by participatory methods and action over time to 'reinforce the alternative forms and categories of knowledge which might have been produced' (Gaventa \& Cornwall 2006: 126). And perhaps the key issue for international donors is to recognize the need for their long-term engagement in supporting a national (and in some nations a provincial) system that builds adaptive capacity by local governments and civil societies (Satterthwaite 2011b: 774).

In the urban field, participatory planning goes against a well-established inclination among African urban planners to take authoritarian top-down measures for the

${ }^{45}$ Case studies are a good method to achieve this (Duminy et al. 2014a) as the use of participatory mapping. 
benefit of the few (Duminy et al. 2014b). Cooperation with local leaders in informal settlements would imply recognition by local and central authorities of alternative forms of development and the freedom of inhabitants to create and possess vernacular knowledge. But, on the contrary, urban planning in Africa has been since the beginning a (desperate) attempt to bring some order into what is perceived as pure chaos. Effective urban participatory planning (that is, empowered participatory governance, which involves rethinking the whole decision-process and the public arena) can produce results and succeed in providing basic infrastructure and services in different contexts (Sclavi 2008). ${ }^{46}$

In the case of the complex implications of adaptation to climate change, decentralised solutions where communities get involved seem preferable to any central solution, particularly in an African context where municipalities are so overstretched financially and in terms of human resources that they cannot do everything themselves. The pace of change needed to adapt to the new conditions created by climate destabilisation cannot be achieved without the active participation of local communities. However, as, until now, African cities have been manufactured by a mix of authoritarianism and laissez-aller, there have been only rare occasions of dialogue between planners, developers, and communities. ${ }^{47}$ The creation of common spaces of permanent dialogue would seem like a prerequisite to addressing the multidimensionality of climate change impact-municipalities can only lead the way by learning how to catalyse innovations and help solutions to emerge ${ }^{48}$.

Participatory planning - co-deciding new adapted infrastructures and new urban schemes - could lead to the participatory management of services and help to guarantee the sustainability of any new investment by reducing the cost of its maintenance. However, the mobilisation of communities on a voluntary basis may have its limits; sustainable services can only survive with a strong collective commitment and if someone is in charge and being paid for their time. Local communities are not immune from exploitation by self-proclaimed leaders, and slum inhabitants often have to pay bribes for substandard services to dubious intermediates with connections to corrupt local politicians (Murray 2008: 115-19, 135-9).

\footnotetext{
${ }^{46}$ There are multiple ways to favour inclusiveness when it comes to urban planning (Lemaire \& Kerr 2017b). Electrification and waste management are good examples where the formal can be articulated to the informal via participatory inclusive processes (Lemaire \& Kerr 2016a, 2016b, Simatele et al. 2017).

${ }^{47} \mathrm{On}$ that matter, small cities may have less access to financial resources and international networks but stronger networks 'within the city', as local elites know each other and have to work together (partly to compensate for the lack of resources). See Pasquini (2020).

${ }^{48}$ Action planning tools are being developed by UN-Habitat to favour sharing and inclusive decision process. See Spaliviero et al. (2020). Existing modelling tools like LEAP can also be used as a way to bring stakeholders together and develop a heuristic approach. See SAMSET http://samsetproject.net/
} 
An alternative is an idea well known in the fashion of public-private partnerships, as the multiplication of private initiatives does not lead to any change without some kind of public support. The emphasis on public-private partnerships is presented in the international aid sphere as the solution to problems that fifty years of international aid have not been able to solve. However, the term public-private partnerships covers different types of partnerships with different types of partners- to partner with small enterprises or local cooperatives is not the same as partnering with large corporations. This is often the latest disguise of privatisation and dispossession of the poor.

In the case of cities, municipalities as public agents could be supporting and coordinating local grass-roots private initiatives and regulating the activities of big providers. Cases of successful inclusive partnerships and integrated plans in urban Africa seem quite rare. ${ }^{49}$ Particularly in the case of adaptation to climate change, this constitutes a handicap as it seems almost impossible to identify and implement climate adaptation measures in a centralised manner. ${ }^{50}$ The creation of local economic systems based on the multiplication of small grass-roots initiatives scaled with the support of municipalities would transform challenges in inclusive business opportunities; this is particularly true for markets which can be created with relatively low entry barriers in terms of capital investment, where small-scale operators can complement the activities of large corporations; instead of trying to regulate and formalise the activities of small-scale operators, local authorities can help them to sustain their activities by creating platforms guaranteeing access to micro-loans and knowledge transfer, and protect them from over-exploitation by the formal sector (Lindell 2010, Brown et al. 2014, Lemaire \& Kerr 2016a, 2016b, Akinsete et al. 2019).

\footnotetext{
${ }^{49}$ Most cases can be found in Latin America (Satterthwaite 2011a). For an example of the limits of participation in not-so-democratic political regimes, see the example of waste management in Tanzania and Zambia (Myers 2005). Even in a relatively democratic open regime like that in Senegal, participation may be encouraged but only to some extent as higher levels of government remain inaccessible (Vedeld et al. 2016, Leclerq 2017).

${ }^{50}$ Some 'early adopter' municipalities in South Africa (like Durban and Cape Town) have more than a decade of experience of integrated development plans taking into account climate change with a growing emphasis on community-based adaptation. For a perspective on the case of Durban, see the work by Roberts (Roberts 2008, 2010, Roberts \& O’Donoghue 2013, Roberts et al. 2016). Nevertheless, even in Cape Town, climate change measures cannot be considered as fully mainstreamed into municipal planning instruments (Taylor 2016, Hickmann \& Stehle 2019, Pieterse et al. 2021).
} 


\section{The process of change}

\section{Competitive ideologies}

The most difficult part of any change is not just to have a vision and share it, but also to pose principles of action based on existing realities. There are different stages in any innovation process. Currently, African municipalities participating in an increasing number of regional and international networks are in the phase of exchanging knowledge (Watson \& Odendaal 2012, Kuinsi 2016, Castán Broto 2017, Ndebele-Murissa et al. 2020). This phase of dissemination of best practice and case studies forms a corpus of novel ideas (Odendaal 2012, Duminy et al. 2014a). But the exposure of a few people to new ideas is not enough. A critical mass of individuals sharing those ideas is needed, and local actors need to build their own networks in their countries (Scott et al. 2019).

Building a permanent forum of exchange with channels of communication opened by local communities/organised citizens groups is, as mentioned before, another prerequisite 'to go beyond the conventional confrontational protests' by which the urban poor seek to influence the government (Satterthwaite 2008) to co-production to access basic services (Mitlin 2008, Fatti \& Patel 2013). ${ }^{51}$ One difficulty is to retain the momentum around any new initiatives (Roberts et al. 2016). Money is an issue and projects need to be sustainably funded; hence the requirement for private local partners that have more flexibility than public administrations and that can raise money for effective service delivery. However, the main obstacle to overcome is, as usual, the existence of complex systems of vested interests with powerful actors who benefit from planning as it is and have no interest in changing the status quo (Watson 2009). Corruption and clientelism are, by nature, not open to any exercise of transparency and so-called good governance, even under the pressure of international NGOs and donors (Gandy 2006).

Furthermore, climate change - even if it has already had a detrimental impact on the everyday life of inhabitants of African cities - could be perceived by the majority as one problem among many, even if perceptions seem to be rapidly changing. ${ }^{52}$

\footnotetext{
${ }^{51}$ Slum Dwellers International, which is a global network of federations of urban poor communities, promotes the idea of militant negotiation (https://sdinet.org/, Dobson 2017) and now has a number of federations in African countries, notably in southern Africa. For the action of a federation in Uganda, see Dobson et al. (2015).

${ }^{52}$ The poor in the Global South are perfectly aware of climate change, contrary to the patronising presentation made in the Global North and by partisans of the status quo in the South, but they have their own perception of a changing climate. See, for instance, McQuaid et al. (2018). Inhabitants of towns along the river Senegal, whose livelihood is directly dependent on weather patterns, have to develop a practical knowledge of climate change (personal interviews, 2020). Climate change is now be perceived as a great threat among policy-influencers in southern African cities (for instance, Steynor et al. 2020).
} 
The emphasis placed by international donors on mitigation measures may be perceived as an example of neocolonialism, as Africans are minor contributors to greenhouse gas emissions; actually, only a minority of urban inhabitants are yet aligned to the same consumption norms as the middle class in OECD cities. ${ }^{53}$

Effectively, renewable energy technologies, soft modes of transport, urban agriculture, and smart cities could easily be caricatured as imported ideas, reflecting first and foremost the concerns of the Western middle class and far from the day-today realities of Africans. But actually some of these 'mitigation measures' like urban agriculture $^{54}$ or soft mobility are not new in African cities, even if they often lack official recognition; they contribute to climate adaptation while preventing African urban inhabitants from becoming high emitters of greenhouse gas emissions. ${ }^{55}$ Some technological fixes could, nevertheless, have a limited impact if they remain perceived as off-ground and do not benefit from local support. Another movement of ideas of so-called intermediate technologies, supposedly more adapted to local realities, has also been categorised by local politicians as a tentative step to keep Africa underdeveloped.

Furthermore, the habit of not listening to local communities-except before election time - is anchored in local practices. Endemic corruption in most African countries hinders the delivery of resilient urban infrastructure and services (Chirisa et al. 2016). ${ }^{56}$ Local politicians can gain more symbolic power and personal monetary rewards by continuing to invest in large-scale infrastructure like highways and roads, central electricity plants, and large waste treatment plants, and may see any alternative paths as useless or as a direct threat to their position of power. The perpetuation of the current system, excluding the majority, is a resource rather than an issue for them, and the protection of the poor and most vulnerable against the impact of climate change could be the very least of their concerns (Satterthwaite 2011b).

\footnotetext{
${ }^{53}$ Mitigation measures promoted by international donors instead of adaptation measures transform climate change into an external problem promoted by external actors with their agenda and their technological solution, reflecting a hierarchy of values and priorities that are far from the concerns of local inhabitants.

${ }^{54}$ Kampala and Nairobi are cities where urban agriculture has been successfully promoted and upscaled (Gore 2018). Urban agriculture is practised by 50 per cent of households in Kampala and is more and more recognised by authorities (Vidal-Merino et al. 2021). But in many African cities, urban agriculture remains an illegal practice or is just tolerated as a temporary use of land (Simatale et al. 2012: 1187-8, Titz \& Chiotha, 2019).

${ }^{55}$ African municipalities are simultaneously engaging with mitigation and adaptation measures (Aylett 2015: 8).

${ }^{56}$ But not all of them and not at the same level, contrary to a vision tainted with racism on Africansevery African country, on that matter, is different. See, for instance, the difference between urban planning enforcement in Uganda and Rwanda (Goodfellow 2013).
} 
Adaptative action to climate change means a shift in the balance of power, which will come from activism and grass-roots initiatives (Ziervogel 2019). Data collection and bottom-up participatory mapping can help to make informal activities more visible and give grass-roots actors a legitimacy to participate in the planning process by recognising the existence of informal settlements (Vergara-Perucich \& Aris-Loyola 2021), paratransit systems (Klopp \& Cavolli 2019), or any other informal activities. Action means differentiated strategies according to the context that evolves within each community. Urban guerrilla operations, which go with the re-appropriation of public space, and participation in local political assemblies, protests, and petitions, have been proven to enable change by eroding the legitimacy of established actors promoting conventional infrastructure, which is nothing more than artefacts from an outdated ideology of progress.

\section{Actions grounded in existing urban morphology}

The temptation of the tabula rasa may always be strong among some urban planners and architects, either because the elements of modernity implemented in African cities seem inadequate to sustain any long-term future or because informal settlements do not fit into the representation by the policymakers of the future of their city (Kloosterbooer 2016: 62-70). The building of entirely new towns has met with variable success (Abubakar \& Doan 2017, Keeton \& Provost 2019). Gated communities and futuristic cities built from scratch and mobilising private investors lead to enclaves of prosperity, which represent the antithesis of urbanity (Lemanski 2006, van Norloos \& Kloosterbooer 2018).

As much as it is not desirable to eradicate informal settlements or constructions erected during colonial times, it does not seem desirable or possible to erase modern buildings that have been built since independence, even when these buildings are aesthetically dubious, inefficient, and costly to maintain. As the stock of buildings can last more than a hundred years, the urban mix of old and new can only be adapted rather than eradicated. Tighter regulations can apply to new constructions only with the active participation of inhabitants who can apply some form of social control and assist public agents, who are too few to enforce them. These regulations should be clear, easy to follow, adapted to the tropical climate, and not a direct transfer of EU regulations. Otherwise, if complicated and disconnected from local practices, the high number of new constructions, which are being built every year, will continue to be built according to the lowest standard.

Retrofitting of the old stock of buildings could give priority to low-cost high-impact measures that help to insulate buildings and adapt them to extreme events. Meanwhile, the poorest living in informal settlements could be targeted first with measures that 
are relatively easy to implement. A good example is the ceiling retrofitting insulation programme in South Africa, which can protect shacks from heat and cold for a small investment (Kirsten 2015, Kimenia et al. 2020). Different energy and environmental audits of the existing stock of buildings and existing infrastructure need to be completed to give a clear picture of the key actions to be achieved in each area; these audits need to be conducted with inhabitants and local communities and their conclusions discussed with them.

Action on buildings should be conducted simultaneously with action on their immediate environment, like easier-access paths to replace narrow paths in informal settlements, a proper drainage system, and the creation of community-managed buffer zones (Table 2). Again, this cannot be achieved with poorly defined objectives but needs to be done with and for local communities.

Table 2. Paths toward low-carbon cities.

\begin{tabular}{|c|c|c|c|}
\hline Current issue & Aim & Example of paths & Main obstacles \\
\hline $\begin{array}{l}\text { Carbon-intensive } \\
\text { buildings to build } \\
\text { and maintain }\end{array}$ & $\begin{array}{l}\text { Use of low-carbon } \\
\text { local materials; use } \\
\text { of decentralised } \\
\text { renewable energies; } \\
\text { passive design }\end{array}$ & $\begin{array}{l}\text { Low-carbon building } \\
\text { standards; nomination of } \\
\text { energy managers in large } \\
\text { buildings; provision of } \\
\text { materials for self- } \\
\text { construction }\end{array}$ & $\begin{array}{l}\text { Mindset in the building } \\
\text { industry and among } \\
\text { contractors; wealth } \\
\text { inequalities }\end{array}$ \\
\hline $\begin{array}{l}\text { Investments geared } \\
\text { toward infrastructure } \\
\text { promoting carbon- } \\
\text { intensive mobility }\end{array}$ & $\begin{array}{l}\text { Transfer to low- } \\
\text { carbon collective or } \\
\text { soft mobility }\end{array}$ & $\begin{array}{l}\text { Reorientation of } \\
\text { infrastructure investments; } \\
\text { inclusion of cyclists and } \\
\text { pedestrians in decision } \\
\text { processes }\end{array}$ & $\begin{array}{l}\text { Local producers } \\
\text { marginalised in favour } \\
\text { of importers/foreign } \\
\text { companies; social status } \\
\text { affirmation and } \\
\text { preservation }\end{array}$ \\
\hline $\begin{array}{l}\text { Informal sector/ } \\
\text { informal settlements } \\
\text { ignored or seen as a } \\
\text { nuisance to be } \\
\text { eradicated }\end{array}$ & $\begin{array}{l}\text { Integration of } \\
\text { informality to provide } \\
\text { support and increase } \\
\text { resilience }\end{array}$ & $\begin{array}{l}\text { Creation of public } \\
\text { platforms of exchange } \\
\text { between officials and } \\
\text { communities-support to } \\
\text { self-organisation movements; } \\
\text { attribution of land rights }\end{array}$ & $\begin{array}{l}\text { Mindset of } \\
\text { policymakers; contempt } \\
\text { for the poor; research } \\
\text { into status quo in } \\
\text { keeping wealth } \\
\text { inequalities }\end{array}$ \\
\hline $\begin{array}{l}\text { Deterioration of } \\
\text { quality of life linked to } \\
\text { chaotic urbanisation }\end{array}$ & $\begin{array}{l}\text { Protect and maintain } \\
\text { the environment of } \\
\text { local communities }\end{array}$ & $\begin{array}{l}\text { Support for the active } \\
\text { management of the } \\
\text { immediate environment; } \\
\text { effective participation in the } \\
\text { design and management of } \\
\text { green spaces }\end{array}$ & $\begin{array}{l}\text { Ignorance of local } \\
\text { communities' } \\
\text { knowledge; land } \\
\text { speculation }\end{array}$ \\
\hline $\begin{array}{l}\text { Top-down urban } \\
\text { planning with } \\
\text { exclusive planning } \\
\text { practices }\end{array}$ & $\begin{array}{l}\text { Inclusive planning } \\
\text { practices favouring a } \\
\text { bottom-up approach }\end{array}$ & $\begin{array}{l}\text { Integration of local } \\
\text { communities in the planning } \\
\text { process at every stage of } \\
\text { planning }\end{array}$ & $\begin{array}{l}\text { Authoritarianism and } \\
\text { contempt for citizenship; } \\
\text { urban dwellers as } \\
\text { subjects ruled by } \\
\text { traditional leaders }\end{array}$ \\
\hline
\end{tabular}




\section{Conclusion: inclusiveness or disintegration?}

Climate adaptation in an African urban context may aim to implement the same ideals of a post-COVID city as in other cities in the world: a city that promotes the well-being of its inhabitants instead of a focus on economic competitiveness, and the promotion of resilience instead of an illusion of wealth due to the unsustainability of the current economic system. The ideology of urban competitiveness and worldclass cities implies nothing less than a permanent war on the poor (Huchzermeyer 2011: 47-68).

African state officials have been, since independence, in denial of the importance of urbanisation. Cities are being viewed as places of unrest and contestation of their power, and they prefer to focus their investment in rural areas. Post-colonial urban planning in Africa has failed to address all the major issues faced by urban dwellers, who often need to fend for themselves in a hostile administrative environment that is incapable of providing them with elementary services. Local authorities and their enforcement agencies are, in most cases, the enemy, and communities have to continually negotiate their survival. Even having the ability to secure a land plot/parcel is an inaccessible dream for the majority.

Urban areas would be easier to manage in a decentralised manner than by a centralised authority, which implies decentralisation/devolvement of public authorities and empowerment of local communities; however, decentralisation in Africa has often failed to give real power to local urban governments (Okpala 2009: 19, Smit \& Pieterse 2014: 148-66, Wisner et al. 2015, Tait \& Euston-Brown 2017, Resnick 2021). The informal and unplanned manner in which African cities are rapidly growing would imply the channelling of the energy of its inhabitants, and a different approach to planning where old-fashioned participation in projects designed by consultants leaves systematic ways for community enablement, with co-design and co-management of urban space in a transparent democratic manner in the pursuit of a radical agenda (Pieterse 2008). The creation of commons seems like a prerequisite: they can be based on common locations more than ethnic groups, as urbanisation should at some point allow transcendence of ethnic divisions.

Climate change brings a new dimension to the issues faced by African cities. The African context means that the impact of climate breakdown adds to already serious and seemingly intractable challenges, while urban planning practitioners are (deliberately or not) turning their backs on the majority of the population and, therefore, are unable to answer their basic needs. The urban crisis that African cities are facing can only be exacerbated by the climate crisis, and inclusive planning approaches are urgently needed, if large parts of African cities are not to be abandonned to their fate with shrinking ghettos of functional areas. 
Urban development, which has taken place naturally along major rivers and the coast, means some cities may completely disintegrate. Others will have more and more difficult access to clean water and enough food supply affordable for the majority. The extreme sensitivity of the most vulnerable inhabitants to food prices is aggravated in cities where the densification of dwellings does not allow self-subsistence farming; some urban areas are again more vulnerable than others. Individual resilience has its limits. Inhabitants have some capacity of adaptation to climate change at an individual level or a community level (Kareem et al. 2020). They can mitigate the impact of flooding by organising the clean-up of drains, they can protect their houses from storms by reinforcing their roofs, and they can keep or establish networks with social relations in rural areas to allow the transit of food. Nevertheless, private initiatives which constitute the majority of action to prevent short-term climate variability cannot compensate for a complete lack of planning in response to long-term climate change (Hunter et al. 2020, Mashi et al. 2020). On the other hand, municipalities have limited capacity for intervention. Institutional adaptation is needed to scale-up good practices of adaptation at a micro-level (Lwasa 2010).

Measures to adapt to climate change are partly similar to measures to mitigate climate change. This implies a shift away from the carbon-intensive lifestyle as a mode of existence for the happy few or as a dream for the poor: the original ideal of suburbia with orderly lines of individual houses and malls relying on intensive consumption of natural resources with artificialisation and disconnection with the environment, which has been an agent of urban growth in the US (Rome 2001), is already taking different forms in the Global South. Urban policies may need to acknowledge that evolution (Keil 2018). But planetary suburbanisation with a long commute to reach places of work cannot be expanded indefinitely around the world, while it is being contested in Western countries. Reducing the need for commuting by mixing urban functions is needed; otherwise shifting the complexity of a city to its periphery is likely to continue.

The question of which city model is desirable needs to be explored concomitantly with the question of which model is practically reachable while considering the realities in which African municipalities evolve. Strategic low-carbon urban planning in sub-Saharan Africa implies clarification of what are the most robust adaptative solutions to climate change and how to implement them in a context of financial poverty and weak governance.

Climate adaptation could mean a car-free city with easy on-foot access to all the basic functions of a city and nature. But the idea of a car-free city where all services needed can be reached by walking may still have a long way to go in the imaginary of African decision-makers, for whom cars are synonymous with modernity. Low-cost/ low-carbon mobility could, nevertheless, be particularly adapted to African cities. 
Existing African cities have limited established infrastructure, which could prove to be an advantage as this gives greater freedom to follow low-carbon pathways. Adaptation measures could easily rely mostly on the large-scale dissemination of existing and proof-tested low-carbon socio-technical solutions, but this implies a deviation from the high-carbon pathway followed by Western cities that would remain inaccessible for the majority of African cities. It may mean embracing new technologies, new materials, and new urban forms but only as long as they can be socially embedded. This implies the rejection of top-down approaches, quick technological fixes, and artificial modernisation, replacing them with bottom-up approaches, mature socio-technical solutions, and grounded modernisation.

A hybrid combination of modern technologies and traditional materials - a modernised tradition leading to vernacular forms of construction-seems like a concrete utopian and realistic near future, as all the elements are in place. However, as the move to vernacular forms of building needs to be part of the change of a whole ecosystem, this includes a shift to new forms of mobility and occupation of urban space. In brief, it requires the acceptance of ways of thinking in urban planning more in phase with local resources and local human capacity, instead of neoliberal-inspired urban planning that keeps so-called world-class cities off-ground and off-context, enslaved to an ideology where cities are seen as in permanent competition in a global world, and the poor remain disposable and removable at will ${ }^{57}$ (Njoh 2009).

The reinvention of the vernacular African city means the auto-creation of lasting sustainable solutions, which does not imply sacrifice but an adaptation of certain lifestyles of a minority and the mobilisation of communities. But the current mindset of urban planners and city officials in search of beautification of the city by making the poor invisible are a significant obstacle for any transition.

If African cities need to move towards low-carbon strategies generically, in a similar manner to those proposed in the cities of the Global North, the way to implement low-carbon solutions has to be adapted to the particular context of African countries: socio-technical differences linked to financial cost considerations and cultural and social differences linked to the particular morphogenesis of African cities mean that a low-carbon urban development has to follow a different path from that of Western cities. African cities currently do not emit the same level of greenhouse gas emissions as their Western counterparts and, therefore, have a specific path to follow by adapting to climate change while retaining a low-carbon footprint. Instead of having to drastically reduce their carbon footprint, they must prevent the adoption

${ }^{57}$ The gentrification and beautification process of cities is not particular to African countries. For an example of neoliberalism and contempt of authorities for the poor in two Asian countries, see Abeyasekera et al. (2019). 
of a high-carbon footprint by the majority and avoid a mimetic effect by reducing the carbon footprint of the burgeoning upper-middle class.

Indeed, sustainable transition has a different meaning for informal settlements and for middle-class and upper-class areas. The first have a low-carbon lifestyle, little economic power, and limited access to political networks: adaptation means mobilising community resources - climate change adaptation is a constraint among others and inhabitants of informal settlements are used to constant adaptation. For the second, transition measures can be somehow similar to the ones taken in OECD countries as these social classes tend to have a carbon-intensive lifestyle, have economic power, and benefit from the recognition of the state or the market (Satterthwaite 2011c). For them, adaptation to climate change can always be done by mobilising capital resources to protect their assets and/or they can migrate to another country. Alternatively, to keep the city liveable, they would have to reduce their urban footprint without 'sacrificing' much, except status symbols; but this abandonment of status symbols may be not conceivable.

Some mitigation measures are also adaptation measures as they reduce the impact of climate change; but more specific adaptation measures are also needed to complete the transition. A well-targeted policy of transition toward a low-carbon city would need to be inclusive and capable of mobilising communities in the long term; the transition to a low-carbon and resilient city would involve some financial resources, and a shared knowledge and methodology; this is not out of reach of African cities even with their limited resources, as the main issue for African cities is actually one of governance. Money scarcity may not be the main constraint, as endogenous financing solutions exist to raise funding (Paulais 2012). Actually the main constraint for African municipalities lies at an institutional level in recognising climate change as a priority and integrating the actions of various departments and stakeholders in order to mobilise existing resources effectively: this implies a change in working methods to favour the coordination and exchange of data between administrative departments and with external stakeholders (Roberts 2010, Taylor et al. 2021). A change of mindset from decision-makers and urban dwellers with a carbon-intensive lifestyle could be the most difficult part; the attitudes of the majority, as the COVID crisis has shown, can change quickly, but also could revert back to 'normal' at the end of the sanitary crisis.

Claims of a new era for the promotion of a healthier, more inclusive, and more sustainable city are not new. Often after major political changes, like the end of apartheid in South Africa, attempts have been made to encourage the inclusion of the poor and to recognise their capacity for self-organisation, but authorities have after a while reverted to the habit of recognising only organised and regulated space (Muray 2008: 140-53). Neoliberalism in its different forms around the world by consecrating the 
role of private developers, and by emphasising good governance with only few stakeholders and excluding the voices of the majority, makes the dream of a healthier sustainable city impossible (Myers 2005: 139-43, Cash 2016). It may be one of the lessons of COVID-19 that strong public intervention and regulation are needed, but can work in a complex world only with the effective democratic participation of everyone-and the creation of commons network governance approaches seem preferable to a strong interventionist state (Oosterveer 2009). Their theorisation should be systematically explored in Africa, as in the rest of the world, as networks of decentralised infrastructure and multilayered governance of political territories combined with the self-organisation of communities may defuse tensions and conflicts; this could help cities to be more resilient and adapt to climate change (Simone 2010, Leal Fihlo et al. 2018). But this will have to reverse a long history of urban planning in Africa which from colonial settlements until today has been built on deliberately pushing aside the majority of urban dwellers into the invisibility of the informal world.

\section{References}

Abeyasekera, A., Maqsood, A., Perera, I., Sajjad, F. \& Jonathan Spencer, J. (2019), 'Discipline in Sri Lanka, Punish in Pakistan: Neoliberalism, Governance, and Housing Compared', Journal of the British Academy, 7(s2): 215-44.

Abubakar, I.R. \& Doan, P.L. (2017), 'Building New Capital Cities in Africa: Lessons for New Satellite Towns in Developing Countries', African Studies, 76(4): 546-65. https://doi.org/10.1080/00020184.2017.1376850

AfDB, OECD \& UNDP (2016), African Economic Outlook-Sustainable Cities and Structural Transformation (Paris, OECD Publishing).

Agyekum, K., Kissi, E. \& Danku, J.C. (2020), 'Professional's Views of Vernacular Building Materials and Techniques for Green Building Delivery in Ghana', Scientific African, 8(July): e00424. https://doi.org/10.1016/j.sciaf.2020.e00424

Akinsete, A., Bhagwan, J., Hicks, C., Knezovich, A., Naidoo, D., Naidoo, V., Pillay, S. (2019), 'The Sanitation Economy Opportunity for South Africa-Sustainable Solutions for Water Security \& Sanitation' (Water Research Commission - Toilet Board Coalition).

Andrade, G.S.M., \& Rhodes, J.R. (2012), 'Protected Areas and Local Communities: An Inevitable Partnership Toward Successful Conservation Strategies?', Ecology and Society, 17(4): 14. https://doi.org/10.5751/ES-05216-170414

Apap, J. (2019), 'The Concept of "Climate Refugee”: Towards a Possible Definition', Briefing European Parliamentary Research Service. https://www.europarl.europa.eu/RegData/etudes/ BRIE/2018/621893/EPRS_BRI(2018)621893_EN.pdf

Asibey, M.O., Poku-Boansi, M. \& Adutwum, I.O. (2021), 'Residential Segregation of Ethnic Minorities and Sustainable City Development. Case of Kumasi, Ghana', Cities, 116: 103297. https://doi.org/10.1016/j.cities.2021.103297

Aylett, A. (2010), 'Participatory Planning, Justice, and Climate Change in Durban, South Africa', Environment and Planning A, 42: 99-115. https://doi.org/10.1068/a4274 
Aylett, A. (2015), 'Institutionalizing the Urban Governance of Climate Change Adaptation: Results of an International Survey', Urban Climate, 14: 4-16. https://doi.org/10.1016/j.uclim.2015.06.005

Bahadur, A.V., Ibrahim, M. \& Tanner, T. (2013), 'Characterising Resilience: Unpacking the Concept for Tackling Climate Change and Development', Climate and Development, 5(1): 55-65. https://doi.org/10.1080/17565529.2012.762334

Bataille, C. (2019), 'Low and Zero Emissions in the Steel and Cement Industries', OECD Issue Paper GGSD Forum, Paris.

Beall, J. (2006), 'Cultural Weapons: Traditions, Inventions and the Transition to Democratic Governance in Metropolitan Durban', Urban Studies, 43(2): 457-73. https://doi.org/10.1080/00420980500416966

Bekker, S. \& Therborn, G. (eds) (2012), Capital Cities in Africa (Cape Town, HSRC Press).

Blair, A. (2012), 'Formal Housing Concepts for Informal Settlements. For in Particular: Khayelitsha', master thesis Norwegian University of Life Science, As.

Brown, D., McGrahahan, G. \& Dodman, D. (2014), 'Urban Informality and Building a More Inclusive, Resilient and Green Economy', working paper, International Institute for Environment and Development, London.

Boutueil, V., Lesteven, G. \& Nemett, L. (2020), 'Toward the Integration of Paratransit in Transportation Planning in African Cities', Transportation Research Record, 2674: 995-1004. https://doi.org/10.1177/0361198120933270

Bulkeley, H. (2013), Cities and Climate Change (London, Routledge). https://doi.org/10.4324/9780203077207

Burgess, R., Carmona, M. \& Kolstee, T. (1997), 'Contemporary Policies for Enablement and Participation: A Critical Review', in The Challenge of Sustainable Cities-Neoliberalism and Urban Strategies in Developing Countries (London, Zed Books), 139-62.

Busayo, T.E., Kalumba, M.A. \& Orimoloye, R.I. (2019), 'Spatial Planning and Climate Change Adaptation Assessment: Perspectives', Habitat International, 90: 101978. https://doi.org/10.1016/j.habitatint.2019.04.005

Campbell, E.H. (2006), 'Economic Globalization from Below: Transnational Refugee Trade Networks in Nairobi', in M.J. Murray \& G. Myers (eds) (2006), Cities in Contemporary Africa (New York, Palgrave Macmillan), 125-47. https://doi.org/10.1057/9780230603349_6

Carmichael, J. (2020), Tactical Urbanism - Making it Happen, ARUP, July.

Cash, C. (2016), 'Good Governance and Strong Political Will: Are They Enough for Transformation?', Land Use Policy, 50: 301-11. https://doi.org/10.1016/j.landusepol.2015.10.009

Castán Broto, V. (2017), 'Urban Governance and the Politics of Climate Change', World Development, 93: 1-15. https://doi.org/10.1016/j.worlddev.2016.12.031

Chatterton, P. (2019), Unlocking Sustainable Cities (London, Pluto Press). https://doi.org/10.2307/j.ctv7vctm4

Chimhowu, A. (2019), 'The 'New' African Customary Land Tenure. Characteristic Features and Policy Implications of a New Paradigm', Land Use Policy, 81: 897-903. https://doi.org/10.1016/j.landusepol.2018.04.014

Chirisa, I., Bandauko, E., Mazhindu, E., Keangwama, N.A. \& Chikowore, G. (2016), 'Building Resilient Infrastructure in the Face of Climate Change in African Cities: Scope, Potentiality and Challenges', Development Southern Africa, 33(1): 113-27. https://doi.org/10.1080/0376835X.2015.1113122

Cilliers, S., du Toit, M., Cilliers, J., Drewe, E. \& Retief, F. (2014), 'Sustainable Urban Landscapes: South African Perspectives on Transdisciplinary Possibilities', Landscape and Urban Planning, 125: 260-70. https://doi.org/10.1016/j.landurbplan.2014.02.009

Coaffe, J. \& Lee, P. (2016), Urban Resilience -Planning for Risk, Crisis and Uncertainty (London, Palgrave Macmillan). 
Cobbinah, P.B. (2021), 'Urban Resilience in Climate Change Hotspot', Land Use Policy, 100: 104948. https://doi.org/10.1016/j.landusepol.2020.104948

Cobbinah, P.B. \& Darkwah R.M. (2017), 'Toward a More Desirable Form of Sustainable Urban Development in Africa', African Geographical Review, 36(3): 262-85. https://doi.org/10.1080/19376812.2016.1208770

Cobbinah, P.B., Asibey, M.O., Opoku-Gyamfi, M. \& Peprah, C. (2019), 'Urban Planning and Climate Change in Ghana', Journal of Urban Management, 8: 261-71. https://doi.org/10.1016/j.jum.2019.02.002

Collier, P., Kirchberger, M. \& Soderbom, M. (2015), 'The Cost of Road Infrastructure in Low and Middle Income Country', Policy Research Working Paper, 7408, World Bank. https://doi.org/10.1596/1813-9450-7408

Coquery, M. (1991), 'Secteur Informel et Production de l'espace urbanisé en Afrique', in C. CoqueryVidrovitch \& S. Nedelec (eds) Tiers-Mondes: l'Informel en question? (Paris, L'Harmattan), 197-213.

Coquery-Vidrovitch, C. (1991), 'L'informel dans les villes africaines: essai d'analyse d'historique et sociale', in C. Coquery-Vidrovitch \& S. Nedelec (eds), Tiers-Mondes: l'Informel en question? (Paris, L'Harmattan), 171-96.

Coquery-Vidrovitch, C. \& Nedelec, S. (eds) (1991), Tiers-Mondes: l'Informel en question? (Paris, L'Harmattan).

Dalberto, S.A., Charton, H. \& Goerg, O. (2013), 'Urban Planning, Housing and the Making of "Responsible Citizens"', in S. Bekker \& L. Fourchard (eds) Governing Cities in Africa (Cape Town, HSRC Press), 43-64.

Davis, M. (2006), Planet of Slums (London, Verso). https://doi.org/10.1111/j.1540-5842.2006.00797.x

Dobson, S. (2017), 'Community-driven Pathways for Implementation of Global Urban Resilience Goals in Africa', International Journal of Disaster Risk Reduction, 26: 78-84. https://doi.org/10.1016/j.ijdrr.2017.09.028

Dobson, S., Nyamweru, H. \& Dodman, D. (2015), 'Local and Participatory Approaches to Building Resilience in Informal Settlements in Uganda', Environment and Urbanization, 27(2): 605-20. https://doi.org/10.1177/0956247815598520

Dodman, D., Leck, H., Rusca, M. \& Colenbrander, S. (2017), 'African Urbanisation and Urbanism: Implications for Risk Accumulation and Reduction', International Journal of Disaster Risk Reduction, 26: 7-15. https://doi.org/10.1016/j.ijdrr.2017.06.029

Douglas, I. (2018), 'The Challenge of Urban Poverty for the Use of Green Infrastructure on Floodplains and Wetlands to Reduce Flood Impacts in Intertropical Africa', Landscape and Urban Planning, 180: 262-72. https://doi.org/10.1016/j.landurbplan.2016.09.025

Douglas, I., Alam, K., Maghenda, M., Mcdonnell, Y., Mclean, L. \& Campbell, J. (2008), 'Unjust Waters: Climate Change, Flooding and the Urban Poor in Africa', Environment \& Urbanization, 20(1): 187-205. https://doi.org/10.1177/0956247808089156

Duminy, J., Andreasen, J., Lerise, F., Odendaal, N. \& Watson, V. (eds) (2014a), Planning and the Case Study Method in Africa-The Planner in Dirty Shoes (New York, Palgrave Macmillan). https://doi.org/10.1057/9781137307958

Duminy, J., Odendaal, N. \& Watson, V. (2014b), 'Case Method and Architecture Education in Uganda', in S. Parnell \& E. Pieterse (eds) (2014), Africa’s Urban Revolution (London, Zed Books), 179-201.

Du Toit, M.J., Ciliers, S.S., Dallimer, M., Goddard, M., Guenat, S. \& Cornelius, S.F. (2018), 'Urban Green Infrastructure and Ecosystem Services in Sub-Saharan Africa', Landscape and Urban planning, 180: 249-61. https://doi.org/10.1016/j.landurbplan.2018.06.001

Falchetta, G., Noussan, M. \& Hammad, A.T. (2021), 'Comparing Paratransit in Seven Major African Cities: An Accessibility and Network Analysis’, Journal of Transport Geography, 94: 103131. https://doi.org/10.1016/j.jtrangeo.2021.103131 
Fatti, C.E. \& Patel, Z. (2013), 'Perceptions and Responses to Urban Flood Risk: Implications for Climate Governance in the South', Applied Geography, 36: 13-23.

https://doi.org/10.1016/j.apgeog.2012.06.011

Fredericks, R. (2018), Garbage Citizenship —Vital Infrastructures of Labor in Dakar, Senegal (Durham, NC, Duke University Press). https://doi.org/10.1215/9781478002505

Gandy, M. (2006), 'Planning, Anti-planning and the Infrastructure Crisis Facing Metropolitan Lagos', Urban Studies, 43(2): 371-96. https://doi.org/10.1080/00420980500406751

Gaventa, J. \& Cornwall, A. (2006), 'Challenging the Boundaries of the Possible: Participation, Knowledge and Power', IDS Bulletin, 37(6): 122-8. https://doi.org/10.1111/j.1759-5436.2006.tb00329.x

Goodfellow, T. (2013), 'Planning and Development Regulation Amid Rapid Urban Growth: Explaining Divergent Trajectories in Africa', Geoforum, 48: 83-93. https://doi.org/10.1016/j.geoforum.2013.04.007

Gore, C.D. (2018), 'How African Cities Lead: Urban Policy Innovation and Agriculture in Kampala and Nairobi', World Development, 108: 169-80. https://doi.org/10.1016/j.worlddev.2018.03.011

Gough, K.V. et al. (2019), 'Vulnerability to Extreme Weather Events in Cities: Implications for Infrastructure and Livelihoods', Journal of the British Academy, 7(s2): 155-81.

Gwilliam, K., Foster, V., Archondo-Callao, R., Briceño-Garmendia, C. \& Nogales, A. \& Sethi, K. (2008), 'The Burden of Maintenance: Roads in Sub-Saharan Africa', Background Paper 14, Africa Infrastructure Country Diagnostic. https://roadsforwater.org/wp-content/ uploads/2013/10/the-burden-of-maintenance_roads-in-SSA.pdf

Harrison, P. (2006), 'On the Edge of Reason: Planning and Urban Futures in Africa', Urban Studies, 43(2): 319-35. https://doi.org/10.1080/00420980500418368

Heisel, F. \& Kifle, B. (eds) (2016), Lessons of Informality-Architecture and Urban Planning for Emerging Territories - Concepts from Ethiopia (Basel, Birkhauser). https://doi.org/10.1515/9783035606706

Hickmann, T. \& Stehle, F. (2019), 'The Embeddedness of Urban Climate Politics in Multilevel Governance: A Case Study of South Africa's Major Cities', Journal of Environment \& Development, 28(1): 54-77. https://doi.org/10.1177/1070496518819121

Huchzermeyer, M. (2011), Cities with 'Slums': From Informal Settlement Eradication to a Right to the city in Africa (Cape Town, UCT Press).

Hunter, N.B., North, M.A, Roberts, D.C. \& Slotow, R. (2020), 'A Systematic Map of Responses to Climate Impacts in Urban Africa', Environmental Research Letters, 15: 103005. https://doi.org/10.1088/1748-9326/ab9d00

IDMC (Internal Displacement Monitoring Centre) (2019), Africa Report on Internal Displacement (Geneva, IDMC).

IEA (International Energy Agency) (2018), The Future of Cooling-Opportunities for Energy-efficient Air Conditioning (Paris, IEA).

Jones, M. (2020), 'Energy Justice in Dhaka’s Slums', PhD thesis, University College London.

Kareem, B. et al. (2020), 'Pathways for Resilience to Climate Change in African Cities', Environmental Research Letters, 15: 073002. https://doi.org/10.1088/1748-9326/ab7951

Kasei, R.A., Kalanda-Joshua, M.D. \& Benefor, D.T. (2019), 'Rapid Urbanisation and Implications for Indigenous Knowledge in Early Warning on Flood Risk in African Cities', Journal of the British Academy, 7(s2), 183-214.

Keeton, R. \& Provost, M. (2019), To Build a City in Africa-A History and a Manual (Rotterdam, Nai010Publishers).

Keil, R. (2018), Suburban Planet (Cambridge, Polity Press). 
Khalil, H.A.E.E., AbdelKhalek, I., Elgendy, N. \& Makhlouf, N. (2018), 'Could/Should Improving the Urban Climate in Informal Areas of Fast-growing Cities Be an Integral Part of Upgrading Processes? Cairo Case', Urban Climate, 24: 63-79. https://doi.org/10.1016/j.uclim.2018.01.007

Kimenia, D., van Niekerk, A., Annegarn, H. \& Seedat, M. (2020), 'Passive Cooling for Thermal Comfort in Informal Housing', Journal of Energy in South Africa, 31: 28-39. https://doi.org/10.17159/2413-3051/2020/v31i1a7689

Kirsten, S. (2015), 'Heat as Medicine-A Study of the Ceiling Retrofit Programme in South Africa Low-cost Housing', master thesis, University of Cape Town.

Kleemann, J., Inkoom, J.N., Thiel, M., Shankar, S., Lautenbach, S. \& Fürst, C. (2017), 'Peri-urban Land Use Pattern and its Relation to Land Use Planning in Ghana, West Africa', Landscape and Urban Planning, 165: 280-94. https://doi.org/10.1016/j.landurbplan.2017.02.004

Kloosterboer, M. (2016), 'A “New” Addis Ababa: Tabula Rasa Versus Upgrading Strategies in City Planning', in F. Heisel \& B. Kifle (eds) Lessons of Informality-Architecture and Urban Planning for Emerging Territories-Concepts from Ethiopia (Basel, Birkhauser), 62-70. https://doi.org/10.1515/9783035606706-005

Klopp, J.M. \& Cavoli, C. (2019), 'Mapping Minibuses in Maputo and Nairobi: Engaging Paratransit in Transportation Planning in African Cities', Transport Review, 39: 657-76. https://doi.org/10.1080/01441647.2019.1598513

Kuinsi, R. (2016), 'Dar es Salaam, Tanzania', in S. Bartlett \& D. Satterthwaite (eds) Cities on a Finite Planet-Towards Transformative Reponses to Climate Change (Abingdon, Routledge), 96-115.

Leal Fihlo, W., Belay, S., Kalangu, J., Menas, W., Munishi, P. \& Musiyiwa, K. (2018), 'Strengthening Climate Change Adaptation Capacity in Africa-Case Studies from Six Major African Cities and Policy Implications', Environmental Science and Policy, 86: 29-37. https://doi.org/10.1016/j.envsci.2018.05.004

Leal Fihlo, W. et al. (2019), 'Assessing the Impacts of Climate Change in Cities and their Adaptive Capacity: Towards Transformative Approaches to Climate Change Adaptation and Poverty Reduction in Urban Areas in a Set of Developing Countries', Sciences of the Total Environment, 692: 1175-90. https://doi.org/10.1016/j.scitotenv.2019.07.227

Leck, H. et al. (2018), 'Towards Risk-sensitive and Transformative Urban Development in Sub Saharan Africa', Sustainability, 10: 2645. https://doi.org/10.3390/su10082645

Leclercq, R. (2017), 'The Politics of Risk Policies in Dakar, Senegal', International Journal of Disaster Risk Reduction, 26: 93-100. https://doi.org/10.1016/j.ijdrr.2017.09.031

Le Corbusier (1929), The City of Tomorrow and Its Planning (New York, Payson \& Clarke).

Le Corbusier (1964), The Radiant City: Elements of a Doctrine of Urbanism to be Used as the Basis of our Machine-age Civilization (New York, Orion Press).

Le Corbusier (1973), The Athens Charter (New York, HarperCollins).

Lemaire, X. \& Kerr, D. (2014), 'International Literature Review on Urban Energy Transitions' (London, UCL Energy Institute / SAMSET). https://www.samsetproject.net/

Lemaire, X. \& Kerr, D. (2016a), 'Waste Management-Innovative Solutions for African Municipalities' (London, UCL Energy Institute / SAMSET). https://www.samsetproject.net/

Lemaire, X. \& Kerr, D. (2016b), 'Informal Settlements_Electrification and Urban Services' (London, UCL Energy Institute / SAMSET). https://www.samsetproject.net/

Lemaire, X., \& Kerr, D. (2017a), 'Gender and Inclusive Urbanisation' (London, UCL Energy Institute / SAMSET). https://www.samsetproject.net/

Lemaire, X. \& Kerr, D. (2017b), 'Inclusive Urban Planning — Promoting Equality and Inclusivity in Urban Planning Practices' (London, UCL Energy Institute / SAMSET). https://www.samsetproject.net/ 
Lemaire X. \& Kerr. D. (2018), 'Thermal Energy Services with Solar Water Heating' (London, UCL Energy Institute / STEPs). http://stepsproject.net/

Lemanski, C. (2006), 'Spaces of Exclusivity or Connection? Linkages Between a Gated Community and its Poorer Neighbour in a Cape Town Master Plan Development', Urban Studies, 43(2): 397-420. https://doi.org/10.1080/00420980500495937

Lindell, I. (2010), Africa's Informal Workers-Collective Agency, Alliances and Trans-national Organizing in Urban Africa (London, Zed Books). https://doi.org/10.5040/9781350218192

Lindley, S., Pauleit, S., Yeshitela, K., Cilliers, S.S. \& Shackleton, C. (2018), 'Rethinking Urban Green Infrastructure and Ecosystem Services from the Perspective of Sub-Saharan African Cities', Landscape and Urban Planning, 180: 328-38. https://doi.org/10.1016/j.landurbplan.2018.08.016

Lwasa, S. (2010), 'Adapting Urban Areas in Africa to Climate Change: The Case of Kampala', Current Opinion in Environmental Sustainability, 2: 166-71. https://doi.org/10.1016/j.cosust.2010.06.009

Lwasa, S., Mugagga, F., Wahab, B., Simon, D., Connors, J. \& Griffith, C. (2013), 'Urban and Periurban Agriculture and Forestry: Transcending Poverty Alleviation to Climate Change Mitigation and Adaptation', Urban Climate, 7: 92-106. https://doi.org/10.1016/j.uclim.2013.10.007

Magigi, W. \& Drescher, A.W. (2010), 'The Dynamics of Land Use Change and Tenure Systems in Sub-Saharan Africa Cities; Learning from Himo Community Protest, Conflict and Interest in Urban Planning in Tanzania', Habitat International, 34: 154-64. https://doi.org/10.1016/j.habitatint.2009.08.004

Mashi, S.A., Inkani, A.I., Obaro, O. \& Asanarimam, A.S. (2020), 'Community Perception, Response and Adaptation Strategies. Towards Flood Risk in Traditional African City', Natural Hazards, 103: 1727-59. https://doi.org/10.1007/s11069-020-04052-2

Massiah, G. \& Tribillon, J.-F. (1987), Villes en Développement (Paris, La Découverte).

McNamara, K.E. \& Buggy, L. (2017), 'Community-based Climate Change Adaptation: A Review of Academic Literature', Local Environment, 22(4): 433-60. https://doi.org/10.1080/13549839.2016.1216954

McQuaid, K., Vanderbeck, R.M., Valentine, G., Liu, C., Chen, L., Zhang, M. \& Diprose, K. (2018), 'Urban Climate Change, Livelihood Vulnerability and Narratives of Generational Responsibility in Jinja. Uganda', Africa, 88: 11-37. https://doi.org/10.1017/S0001972017000547

Mensah, C.A. (2014), 'Urban Green Spaces in Africa: Nature and Challenges', International Journal of Ecosystem, 4(1): 1-11.

Millington, N. \& Scheba, S. (2021), 'Day Zero and the Infrastructures of Climate Change: Water Governance, Inequality, and Infrastructural Politics in Cape Town's Water Crisis', International Journal of Urban and Regional Research, 45(1): 116-32. https://doi.org/10.1111/1468-2427.12899

Mitlin, D. (2008), 'With and Beyond the State - Co-production as a Route to Political Influence, Power and Transformation for Grassroots Organizations', Environment \& Urbanization, 20(2): 339-60. https://doi.org/10.1177/0956247808096117

Muller, M. (2017), 'Understanding the Origin of Cape Town's Water Crisis', Civil Engineering, 25(5): $11-16$.

Murray, M.J. (2008), Taming the Disorderly City-The Spatial Landscape of Johannesburg after Apartheid (Ithaca, NC, Cornell University Press). https://doi.org/10.7591/9781501717000

Myers, G.A. (2005), Disposable Cities (Farnham, Ashgate).

Myers, G. (2011), African Cities: Alternative Visions of Urban Theory and Practice, London (New York, Zed Books). https://doi.org/10.5040/9781350218123

Ndebele-Murisa et al. (2020), 'City to City Learning and Knowledge Exchange for Climate Resilience in Southern Africa', PLOS ONE, 15(1). https://doi.org/10.1371/journal.pone.0227915 
Nguyen, A.T., Truong, N.S.H., Rockwood, D. \& Le, A.D.T. (2019), 'Studies on Sustainable Features of Vernacular Architecture in Different Regions Across the World: A Comprehensive Synthesis and Evaluation', Frontiers of Architectural Research, 8: 535-48. https://doi.org/10.1016/j.foar.2019.07.006

Niang, I., Ruppel, O.C. et al. (2014), 'Africa', in V.R. Barros et al.(eds) Climate Change 2014: Impacts, Adaptation, and Vulnerability. Part B: Regional Aspects. Contribution of Working Group II to the Fifth Assessment Report of the Intergovernmental Panel on Climate (Cambridge, Cambridge University Press), 1199-265.

Njoh, A.J. (2009), 'Ideology and Public Health Elements of Human Settlement Policies in sub-Saharan Africa', Cities, 26: 9-18. https://doi.org/10.1016/j.cities.2008.11.003

Njoh, A.J. (2012), Urban Planning and Public Health in Africa (Farnham, Ashgate).

Nuvanna, C. (2015), 'Gentrification in Nigeria: The Case of Two Housing Estates in Lagos', in L. Lees, H. Bang Shin \& E. Lopes-Morales (eds) Global Gentrifications-Uneven Development and Displacement (Bristol, Policy Press), 311-27.

Odendaal, N. (2012), 'Reality Check: Planning Education in the African Urban Century', Cities, 29: 174-82. https://doi.org/10.1016/j.cities.2011.10.001

OECD (2020), 'Cities Policy Response-Tackling Coronavirus (COVID-19): Contributing to a Global Effort', Note July 2020.

Okpala, D. (2009), 'Regional Overview of the Status of Urban Planning and Planning Practice in Anglophone (Sub-Saharan) African Countries. Regional Study Prepared for Revisiting Urban Planning: Global Report on Human Settlements' (UN-Habitat).

Oosterveer, P. (2009), 'Urban Environmental Services and the State in East Africa; Between Neodevelopmental and Network Governance Approaches', Geoforum, 40: 1061-8. https://doi.org/10.1016/j.geoforum.2009.08.009

Padgham, J., Jabbour, J. \& Dietrich, K. (2015), 'Managing Change and Building Resilience: A multistressor Analysis of Urban and Peri-urban Agriculture in Africa and Asia', Urban Climate, 12: 183-204. https://doi.org/10.1016/j.uclim.2015.04.003

Parnell, S. \& Walawege, R. (2014), 'Sub-Saharan African Urbanisation and Global Environmental Change', in S. Parnell \& E. Pieterse (eds) Africa's Urban Revolution (London, Bloomsbury Academic), 35-9. https://doi.org/10.5040/9781350218246.ch-003

Pasquini, L. (2020), 'The Urban Governance of Climate Change Adaptation in Least-developed African Countries and in Small Cities: The Engagement of Local Decision-makers in Dar es Salaam, Tanzania, and Karonga, Malawi', Climate and Development, 12(5): 408-19. https://doi.org/10.1080/17565529.2019.1632166

Pasquini, L., van Ardenne, L., Godsmark, C.N., Lee, J. \& Jack, C. (2020), 'Emerging Climate Changerelated Public Health Challenges in Africa: A Case Study of the Heat-health Vulnerability of Informal Settlement Residents in Dar es Salaam, Tanzania', Science of the Total Environment, 747: 141355.

Paulais, T. (2012), Financing Africa's Cities-The Imperative of Local Investment (Paris, Agence Française de Développement; Washington, DC, World Bank). https://doi.org/10.1596/978-0-8213-9455-7

Pieterse, E. (2006), 'Building with Ruins and Dreams: Some Thoughts on Realising Integrated Urban Development in South Africa through Crisis', Urban Studies, 43(2): 285-304. https://doi.org/10.1080/00420980500404020

Pieterse, E. (2008), CityFutures - Confronting the Crisis of Urban Development (London, Zed Books; Cape Town, UCT Press). https://doi.org/10.5040/9781350219199

Pieterse, A., du Toit, J. \& van Niekerk, W. (2021), 'Climate Change Adaptation Mainstreaming in the Planning Instruments of Two South African Local Municipalities', Development Southern Africa, 38(4): 493-508. https://doi.org/10.1080/0376835X.2020.1760790 
Pirie, G. (2014), 'Transport Pressures in Urban Africa: Practices, Policies, Perspectives', in S. Parnell \& E. Pieterse (eds) Africa's Urban Revolution (London, Zed Books), 133-47.

Pitcher, M.A. \& Graham, A. (2006), 'Cars are Killing Luanda', in M.J. Murray \& G. Myers (eds) (2006), Cities in Contemporary Africa (New York, Palgrave Macmillan), 173-94. https://doi.org/10.1057/9780230603349_8

Planitz, E. (2019), 'Neglecting the Urban? Exploring Rural-Urban Disparities in the Climate Change Conflict Literature on Sub-Saharan Africa', Urban Climate, 30 (December). https://doi.org/10.1016/j.uclim.2019.100533

Polomack, A. (2010), 'Mixity and Territoriality in a Rapidly Expanding City: How Dar es Salaam was Shaped by its Suburbs', in B. Calas (ed.) From Dar Es Salaam to Bongoland-Urban Mutations in Tanzania (Paris, Karthala), 125-95.

Potts, D. (2006), 'City Life in Zimbabwe at a Time of Fear and Loathing: Urban Planning, Urban Poverty and Operation Murambatsvina', in M.J. Murray \& G. Myers (eds) Cities in Contemporary Africa (New York, Palgrave Macmillan), 265-88. https://doi.org/10.1057/9780230603349_13

Ratho, A. \& Lourdes John, P. (eds) (2020), Rethinking Cities in a Post-Covid-19 World (Oxford, Wiley-Blackwell).

Resnick, D. (2021), 'The Politics of Urban Governance in Sub-Saharan Africa', Regional and Federal Studies, 31(1): 139-61. https://doi.org/10.1080/13597566.2020.1774371

Rice, S.E. \& Patrick, S. (2008), Index of State Weakness in the Developing World (Washington DC, Brookings Global Economy and Development-Foreign Policy at Brookings).

Rigon, A. (2014), 'Building Local Governance: Participation and Elite Capture in Slum-upgrading in Kenya', Development and Change, 45(2): 257-83. https://doi.org/10.1111/dech.12078

Roberts, D. (2008), 'Thinking Globally, Acting Locally_-Institutionalizing Climate Change at the Local Government Level in Durban, South Africa', Environment \& Urbanization, 20(2): 521-37. https://doi.org/10.1177/0956247808096126

Roberts, D. (2010), 'Prioritizing Climate Change Adaptation and Local Level Resilience in Durban, South Africa', Environment \& Urbanization, 22(2): 397-413. https://doi.org/10.1177/0956247810379948

Roberts, D. \& O’Donoghue, S. (2013), 'Urban Environmental Challenges and Climate Change Action in Durban, South Africa', Environment \& Urbanization, 25(2): 299-319. https://doi.org/10.1177/0956247813500904

Roberts, D., Morgan, D., O’Donoghue, S., Guastella, L. Hlongwa, N. \& Price, P. (2016), 'Durban, South Africa', in S. Bartlett \& D. Satterthwaite (eds) Cities on a Finite Planet-Towards Transformative Reponses to Climate Change (Abingdon, Routledge), 96-115.

Rome, A. (2001), The Bulldozer in the Countryside. Suburban Sprawl and the Rise of American Environmentalism (Cambridge, Cambridge University Press). https://doi.org/10.1017/CBO9780511816703

Roy, M., Shemdoe, R., Hulme, D., Mwageni, N. \& Gough, A. (2018), 'Climate Change and Declining Level of Green Structures: Life in Informal Settlements of Dar es Salaam, Tanzania', Landscape and Urban Planning, 180: 282-93. https://doi.org/10.1016/j.landurbplan.2017.11.011

Sarzynski, A. (2015), 'Public Participation, Civic Capacity, and Climate Change Adaptation in Cities', Urban Climate,14: 52-67. https://doi.org/10.1016/j.uclim.2015.08.002

Satterthwaite, D. (2008), 'The Social and Political Basis for Citizen Action on Urban Poverty', Environment \& Urbanization, 20(2): 307-18. https://doi.org/10.1177/0956247808096114

Satterthwaite, D. (2011a), 'Why is Community Action Needed for Disaster Risk Reduction and Climate Change Adaptation?', Environment \& Urbanization, 23(2): 339-49. https://doi.org/10.1177/0956247811420009 
Satterthwaite, D. (2011b), 'How can Urban Centers Adapt to Climate Change With Ineffective or Unrepresentative Local Governments?', WIREs Climate Change, 2: 767-76. https://doi.org/10.1002/wcc.136

Satterthwaite, D. (2011c), 'How Urban Societies can Adapt to Resource Shortage and Climate Change', Philosophical Transactions of the Royal Society, 369: 1762-83. https://doi.org/10.1098/rsta.2010.0350

Satterthwaite, D. (2017), 'The Impact of Urban Development on Risk in Sub-Saharan Africa's Cities with a Focus on Small and Intermediate Urban Centres', International Journal of Disaster Risk Reduction, 26: 16-23. https://doi.org/10.1016/j.ijdrr.2017.09.025

Sclavi, M. (2008), 'Governance and Consensus Building', in R. Plunz \& M.P. Sutto (eds) Urban Climate Change Cross Road (Farnham, Ashgate), 103-10.

Scott, D., Davies, H. \& New, M. (2019), Mainstreaming Climate Change in Urban Development (Cape Town, UCT Press).

Sharifi, A. \& Khavarian-Garmsir, A.R. (2020), 'The COVID-19 Pandemic: Impact on Cities and Major Lessons for Urban Planning, Design and Management', Science of the Total Environment, 749: 142391. https://doi.org/10.1016/j.scitotenv.2020.142391

Silva, C.N. (ed.) (2015), Urban Planning in Sub-Saharan Africa-Colonial and Post-colonial Planning Cultures (New York, Routledge). https://doi.org/10.4324/9781315797311

Simatele, D., Binns, T. \& Simatale, M. (2012), 'Sustaining Livelihoods under a Changing Climate: The Case of Urban Agriculture in Lusaka, Zambia', Journal of Environmental Planning and Management, 55(9): 1175-91. https://doi.org/10.1080/09640568.2011.637688

Simatele, D.M, Dlamini, S. \& Kubanza, N.Z. (2017), 'From Informality to Formality: Perspectives on the Challenges of Integrating Solid Waste Management into the Urban Development and Planning Policy in Johannesburg, South Africa', Habitat International, 63: 122-30. https://doi.org/10.1016/j.habitatint.2017.03.018

Simon, D. et al. (2021), 'Cities Coping with COVID — Comparative Perspectives', City, 25(1-2): 129-70. https://doi.org/10.1080/13604813.2021.1894012

Simone, A. (2004), For the City Yet to Come - Changing African Life in Four Cities (Durham, NC, Duke University Press). https://doi.org/10.1515/9780822386247

Simone, A. (2010), City Life from Jakarta to Dakar-Movements at the Crossroads (New York, Routledge). https://doi.org/10.4324/9780203892497

Simone, A. \& Abouhani, A. (2005), Urban Africa-Changing Contours of Survival in the City (Dakar, Codesria; London, Zed Books).

Simpson, N.P., Shearing C.D. \& Dupont, B. (2020), 'Gated Adaptation During the Cape Town Drought: Mentalities, Transitions and Pathways to Partial Nodes of Water Security', Society \& Natural Resources, 33(8): 1041-9. https://doi.org/10.1080/08941920.2020.1712756

Smit, W. \& Pieterse, E. (2014), 'Decentralisation and Institutional Reconfiguration in Urban Africa', in S. Parnell \& E. Pieterse (eds) Africa's Urban Revolution (London, Zed Books), 148-66. https://doi.org/10.5040/9781350218246.ch-008

Spaliviero, M., Pelling, M., Lopes, L.F., Tomaselli, C., Rochell, K. \& Guambe, M. (2020), 'Resilience Planning under Information Scarcity in Fast-growing African Cities and Towns: The CityRAP Approach', International Journal of Disaster Risk Reduction, 44: 101419. https://doi.org/10.1016/j.ijdrr.2019.101419

Steynor, A., Leighton, M., Kavonic, J., Abrahams, W., Magole, L. Kaunda, S. \& Mubaya, C.P. (2020), 'Learning from Climate Change Perceptions in Southern African Cities', Climate Risk Management, 27: 100202. https://doi.org/10.1016/j.crm.2019.100202

Tait, L. \& Euston-Brown, M. (2017), 'What Role can African Cities Play in Low-carbon Development? A Multilevel Governance Perspective of Ghana, Uganda and South Africa', Journal of Energy in Southern Africa, 28 (3): 43-53. https://doi.org/10.17159/2413-3051/2017/v28i3a1959 
Taylor, A. (2016), 'Institutional Inertia in a Changing Climate-climate Adaptation Planning in Cape Town, South Africa', International Journal of Climate Change Strategies and Management, 8(2): 194-211. https://doi.org/10.1108/IJCCSM-03-2014-0033

Taylor, A., Jack, C., McClure, A., Bharwani, S., Ilinga, R. \& Kavonic, J. (2021), 'Understanding and Supporting Climate-sensitive Decision Processes in Southern African Cities', Current Opinion in Environmental Sustainability, 51: 77-84. https://doi.org/10.1016/j.cosust.2021.03.006

Titz, A. \& Chiotha, S. (2019), 'Pathways for Sustainable and Inclusive Cities in Southern and Eastern Africa through Urban Green Infrastructure?' Sustainability, 11: 2729. https://doi.org/10.3390/su11102729

UNCHR (2016), 'Global Trends: Forced Displacement in 2016', United Nations High Commissioner for Refugees. https://www.unhcr.org/uk/statistics/unhcrstats/5943e8a34/global-trends-forceddisplacement-2016.html

UN-DESA (2015), World Urbanization Prospects: The 2014 Revision: Population of Urban Agglomerations with 300,000 Inhabitants or More in 2014, United Nations Department of Economic and Social Affairs. https://population.un.org/wup/publications/files/wup2014-report.pdf

UNEP (2020), Used Vehicles and the Environment-A Global Overview of Used Light Duty Vehicles: Flow, Scale and Regulation (Nairobi, UN Environment Programme). https://wedocs.unep.org/ bitstream/handle/20.500.11822/34298/KFUVE.pdf?sequence=1\&isAllowed=y

UN-Habitat (2011), Affordable Land and Housing in Africa (Nairobi, UNON). https://unhabitat.org/ sites/default/files/download-manager-files/Affordable $\% 20$ Land $\% 20$ and $\% 20$ Housing $\% 20 \mathrm{in} \% 20$ Africa.pdf

UN-Habitat (2016), Slum Almanac 2015 2016 - Tracking Improvement in the Lives of Slum Dwellers (Nairobi, UNON). https://unhabitat.org/sites/default/files/documents/2019-05/slum_ almanac_2015-2016_psup.pdf

UN-Habitat (2018), Pro-poor Climate Action in Informal Settlements (Nairobi, UNON). https:// unhabitat.org/sites/default/files/2019/05/pro-poor_climate_action_in_informal_settlements-.pdf

UN-Habitat (2020), COVID-19 in African Cities-Impact, Responses and Policies (Nairobi, UNON). https://unhabitat.org/sites/default/files/2020/09/hsp-eb-2020-inf_3_-_covid-19_response_-_full_ report.pdf

van Norloos, F. \& Kloosterbooer, M. (2018), 'Africa’s New Cities: The Contested Future of Cities', Urban Studies, 55(6): 1223-41. https://doi.org/10.1177/0042098017700574

Vedeld, T., Coly, A., Ndour, N.M. \& Hellevik, S. (2016), 'Climate Adaptation at what Scale? Multi-level Governance, Resilience, and Coproduction in Saint-Louis Senegal', Natural Hazards, 82: 173-99. https://doi.org/10.1007/s11069-015-1875-7

Venter, Z.S., Shackleton, C.M., Van Staden, F., Selomane, O. \& Masterson, V.A. (2020), 'Green Apartheid: Urban Green Infrastructur Remains Unequally Distributed Across Income and Race Geographies in South Africa', Landscape and Urban Planning, 203: 103889. https://doi.org/10.1016/j.landurbplan.2020.103889

Vergara-Perucich, F. \& Aris-Loyola, M. (2021), 'Community Mapping with a Public Participation Geographic Information System in Informal Settlements', Geographical Research, 59: 268-84. https://doi.org/10.1111/1745-5871.12458

Vidal Merino, V., Gajjar, S.P., Subedi, A., Polgar, A. \& Van Den Hoof, C. (2021), 'Resilient Governance Regimes that Support Urban Agriculture in Sub-Saharan Cities: Learning from Local Challenges', Frontiers in Sustainable Food Systems, 5: 692167. https://doi.org/10.3389/fsufs.2021.692167

Watson, V. (2009), “"The Planned City Sweeps the Poor Away...”: Urban Planning and 21st Century Urbanisation', Progress in Planning, 72: 151-93. https://doi.org/10.1016/j.progress.2009.06.002 
Watson, V. \& Odendaal, N. (2012), 'Changing Planning Education in Africa: The Role of the Association of African Planning Schools', Journal of Planning Education and Research, 33(1): 96-107. https://doi.org/10.1177/0739456X12452308

Williams D.S., Costa, M.M., Sutherlands, C., Celliers, L. \& Scheffran, J. (2019), 'Vulnerability of Informal Settlements in the Context of Rapid Urbanization and Climate Change', Environment \& Urbanization, 31(1): 157-76. https://doi.org/10.1177/0956247818819694

Wisner, et al. (2015), 'Small Cities and Towns in Africa: Insights into Adaptation Potentials', in S. Pauleit et al. (eds) Urban Vulnerability and Climate Change in Africa (New York, Springer), 153-96. https://doi.org/10.1007/978-3-319-03982-4_5

World Bank (2014), Making Roads Safer (Washington, DC, World Bank).

Wu, X., Lu, Y., Zhou, S., Chen, L. \& Xu, B. (2016), 'Impact of Climate Change on Human Infectious Diseases: Empirical Evidence and Human Adaptation', Environment International, 86: 14-23. https://doi.org/10.1016/j.envint.2015.09.007

Ziervogel, G. (2019), 'Building Transformative Capacity for Adaptation Planning and Implementation that Works for the Urban Poor: Insights from South Africa', Ambio, 48: 494-506. https://doi.org/10.1007/s13280-018-1141-9

To cite the article: Xavier Lemaire (2021), 'Climate change and strategic low-carbon planning in African cities after COVID-19: inclusiveness or chaos?', Journal of the British Academy, 9(s9): 39-79.

DOI https://doi.org/10.5871/jba/009s9.039

Journal of the British Academy (ISSN 2052-7217) is published by

The British Academy, 10-11 Carlton House Terrace, London, SW1Y 5AH

www.thebritishacademy.ac.uk 
